\title{
ProvenanCE AND ALTERATION OF GLACIAL SEDIMENTS IN KING GEORGE IsLAND, ANTARCTICA
}

\section{Caio Vinícius Gabrig Turbay Rangel ${ }^{1 *}$, Marcos Tadeu D'AZeredo Orlando ${ }^{2}$, Hannah almeida

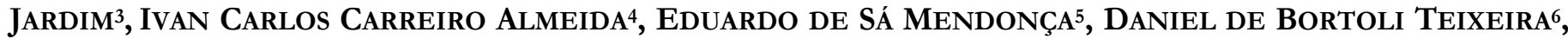 ANDRÉ THOMAZINI ${ }^{7}$ AND CARLOS ERNESTO SCHAEFER ${ }^{7}$}

1 Universidade Federal do Sul da Bahia, Centro de Formação em Ciências Ambientais (CFCAm), Porto Seguro, Bahia, BA, Brazil

2 Universidade Federal do Espírito Santo (UFES), Departamento de Física, Alegre, Espírito Santo, ES, Brazil

3 Universidade Federal de Ouro Preto (UFOP), Departamento de Geologia, Escola de Minas, Minas Gerais, MG, Brazil

4 Instituto Federal do Norte de Minas Gerais, Minas Gerais, MG, Brazil

5 Universidade Federal do Espírito Santo (UFES), Departamento de Produção Vegetal, Alegre, ES, Brazil

6 Universidade Estadual Paulista (UNESP), Departamento de Ciências Exatas, São Paulo, SP, Brazil

7 Universidade Federal de Viçosa (UFV), Departamento de Solos, Viçosa, Minas Gerais, MG, Brazil

*Corresponding Author, cturbay@gmail.com

Received on 3 February 2019

Received in revised form on 30 March 2019

Accepted on 31 March 2019

Editor: Mauro Geraldes, Universidade do Estado do Rio de Janeiro

\section{Abstract}

Mineralogical and geochemical data of glacial sediments of Low Head, King George Island, Antarctica, are presented to approach its provenance and alterations aspects. Mineralogical analyses were performed using petrography and an x-ray diffraction method, while the geochemistry was performed by x-ray fluorescence. Comparisons using major elements in the sediments with possible source areas, suggested that they are closer to the King George Island parent rocks, with no contribution of rocks from Antarctic Peninsula. The gravel and sand fractions demonstrate that the till is composed of basaltic and andesitic rock fragments, plagioclase, pyroxene and amphibole, typical of active immature volcanic arc. The mud fraction indicates chemical characteristics consistent with calc-alkaline to tolleitic and metalluminous affinity of source rock of the till and the presence of secondary mineral phases, such as laumontite,

\section{Introduction}

On King George Island, Maritime Antarctica, the warming that has taken place during the last several decades have been accompanied by rapid glacial retreat and considerable ice wastage (Cook et al., 2005; Rückamp et al., 2011). This process has exposed large rock outcrops and
Citation:

Rangel, C.V.G.T., Orlando, M.T.A., Jardim, H.A., Almeida, I.C.C., Mendonça, E.S., Teixeira, D.B., Thomazini, A., Schaefer, C.E., 2019. Provenance and alteration of glacial sediments in King George Island, Antarctica. Journal of Sedimentary Environments, 4 (1): 124-142.

brucite and saponite. The values of alteration indices, such as the chemical index of alteration (CIA) and the $\mathrm{SiO}_{2} / \mathrm{Al}_{2} \mathrm{O}_{3}$ ratio, in the regional rocks and sediments reflect a remarkable degree of alteration, possibly due to hydrothermal activity, exemplified by the presence of laumontite. In addition, bivariate chemical diagrams suggest slight weathering compared to the South Shetland Islands, which may have been responsible for the formation of brucite and saponite. The results suggest that although there are secondary mineral products, some grade of weathering could have acted in the till during sedimentary cycles or the till was strongly influenced by components of local weathered basalts.

Keywords: Sediment provenance. Alteration. Glaciogenic sediments. Mineralogy. Geochemistry.

deposited glaciogenic sediments (till) in the shore regions, forming large proglacial plains.

These plains are a good laboratory to understand the structural, textural and compositional nature of till in Antarctica. Although many studies have described the 
regolithic material on King George Island, these studies have focused on soil formation and soil properties (for example, Michel et al., 2006; Schaefer et al., 2008; Simas et al., 2008).

The till compositional characteristics at different locations on King George Island have been attributed to the specific local parent volcanic materials (Monien et al., 2011), which are mainly basalts, andesites and its pyroclastic products. On the other hand, some source rocks from Antarctic Peninsula are suggested during Oligocene to Miocene times (Birkenmajer, 1980, 1992a, 1992b; Dingle and Lavelle, 1998).

Chemical characteristics of Mesozoic to Cenozoic parental rocks of South Shetlands indicate predominantly a calc-alkaline to tholeiitic affinity in an active magmatic arc (Birkenmajer et al., 1991, 1994; Yeo et al., 2004; Machado et al., 2005). To the northern Antarctic Peninsula, the Jurassic to Late Cretaceous, acid to intermediate magmatism indicate predominantly a calc-alkaline affinity,
RESEARCH PAPER

in a mature arc, similar to the western South America (Saunders et al., 1980; Birkenmajer, 1994).

In the point of view of weathering, Robert and Kennet (1997), based on clay content and oxygen isotope identified slight chemical weathering in Antarctica, during EoceneOligocene times. Santos et al. (2007) analyzed the coastal sediments in Admiralty Bay, King George Island and demonstrated that no significant alteration due to the weathering occurred in the sedimentary environment. Mineralogical studies carried out on continental shelf sediments collected from the South Shetland Islands (Jeong et al., 2001, 2004) and a core obtained from Maxwell Bay on King George Island (Monien et al., 2011) suggest that the presence of clay minerals reflects hydrothermal alteration of volcanic bedrock. Mineralogical and geochemical studies of the till of Low Head, King George Island (Fig. 1), were performed. The purpose of this work is to characterize the composition of the till and provide more information on its provenance and alteration.

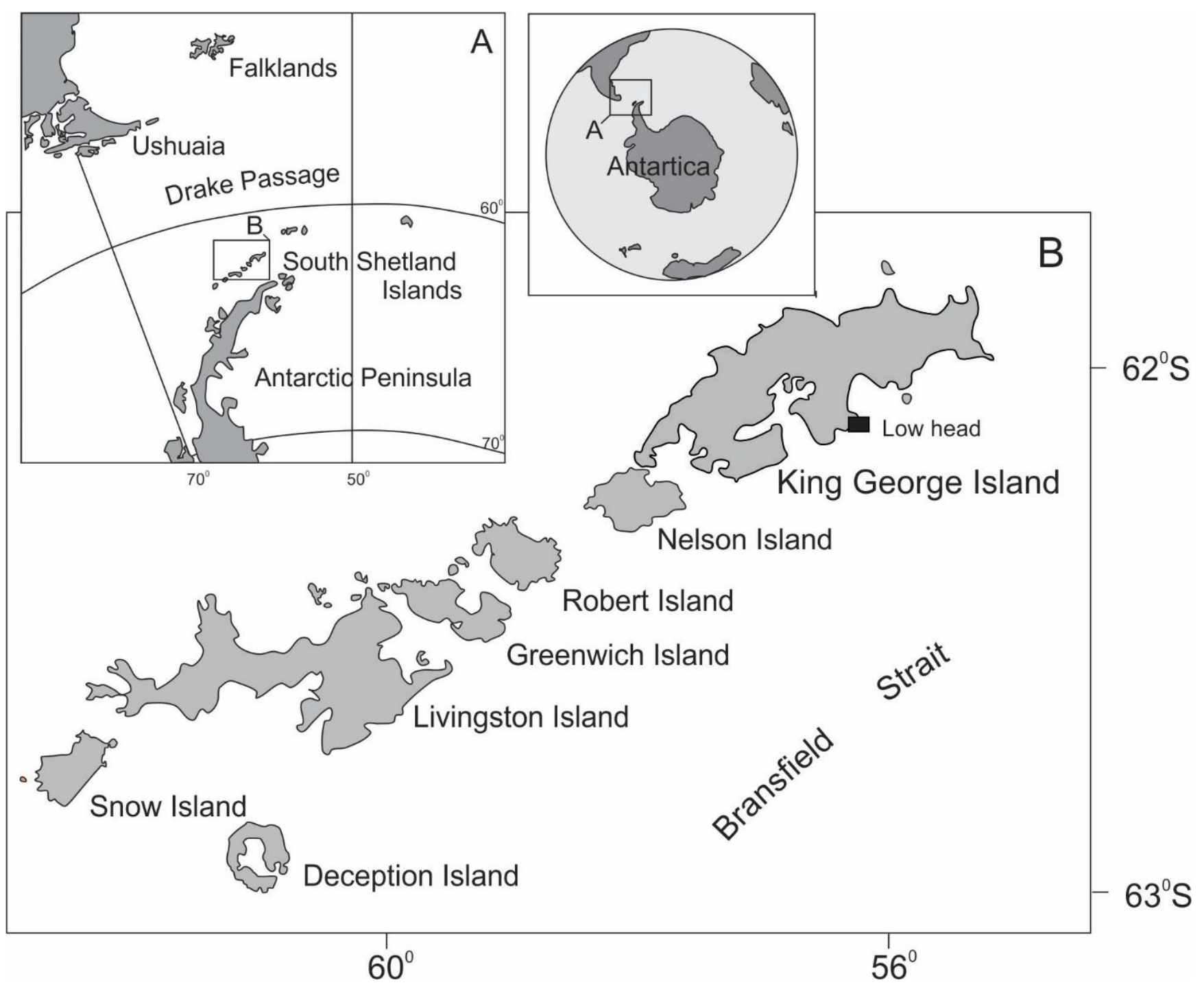

Fig. 1. Location of the South Shetland Islands archipelago and Antarctic Peninsula (A) and the Low Head area at King George Island (B). 


\subsection{Geological overview}

The Antarctic Peninsula is associated with domains that represent the amalgamation of some suspect terranes (Vaughan and Storey, 2000), although most of them are parautochthonous. They are related to turbiditic sequences in an accretionary wedge (the Trinity Peninsula Group and Le May Group; Birkenmajer, 2001; Hervé et al., 2006); low grade metamorphic complex (the Scotia Complex); Jurassic to Lower Cretaceous basaltic and andesitic lavas (the Antarctic Peninsula Volcanic Group) and their hypabyssal to plutonic correlated (Gledhill et al., 1982); Cretaceous calc-alkaline granitoids (the Andean Intrusive Suite; Hawkes, 1961; Barton, 1965). These units have their correspondent in the Patagonian and Fuegan segments of the Andes (Hervé et al., 2006), representing the continuity of the orogenic process in the west margin of Gondwana in the Paleozoic/Mesozoic times, before the breakup (Dalziel, 1984; Trouw et al., 1997).

The Trinity Peninsula Group was deposited during the Permian-Triassic, in the fore-arc region, as a turbiditic association of pelites and wackes, with associated pillows and hyaloclastites, metamorphosed in prehnite-pumpellyite facies (Hyden and Tanner, 1981; Hervé et al., 2006). In the back-arc region, during the Middle to Upper Jurassic, on the erosive discontinuity of the Trinity Peninsula Group, lacustrine and alluvial sedimentary beds of Mount Flora Formation were deposited. In the Middle Jurassic-Early Cretaceous, this crustal section was affected by the calcalkaline, intermediate to acid magmatism of the Antarctic Peninsula Volcanic Group (Birkenmajer, 1994, 2001).

During the Mid to Upper-Cretaceous, the plutons of the Andean Intrusive Suite intrudes the previous units, while the subduction process evolves, and the magmatic arc shift to the west, beginning the formation of the South Shetlands arc, extended through the Miocene age (Birkenmajer, 1994; Hervé et al., 2006). This migration induces in the Oligocene-Recent, an extensional regime into the lithosphere, between the inner magmatic arc (Antarctic Peninsula) and the Shetland Arc, opening the Bransfield Rift (Birkenmajer, 1992a, 1994).

The tectonic scenery of the opening of the Bransfield back-arc and the counterclockwise rotation of the Antarctic continent during the Tertiary, induces to a terrestrial and submarine volcanic activity and the establishment of a set of stike-slip faults in the South Shetland. The chemical signature of the magmatism is predominantly calc-alkaline and tholeiitic (Birkenmajer, 1994, 2001). Based on this hypothesis, the King George Island inherits a framework dominated by tectonic blocks separated by shear zones (Fig. $2 \mathrm{~A})$. These blocks are predominantly made up of basaltic to andesitic lava flows with minor amounts of plugs, dikes, sills and pyroclastic deposits.

In the Early Oligocene, the largest Tertiary glaciation on King George Island was established and a large ice platform was formed, transporting sediments from the Antarctic Peninsula to the South Shetland, depositing the glaciogenic sediments of Polonez Cove Formation (Birkenmajer, 1992a, 1992b; Dingle and Lavelle, 1998).

The region of Wesele Cove, Low Head and Lions Cove, Krakov Block, a set of effusive, pyroclastic, intrusive rocks and correlated sedimentary products were formed during Eocene to Miocene, including the Polonez Cove Formation. These rocks are intruded by Miocene basalts of the Cape Syrezol Group (Birkenmajer, 1989) (Fig. 2B and 2C). The chemical signature in these areas is predominantly calc-alkaline, metaluminous (Birkenmajer et al., 1991).

\section{Materials and Methods}

The field works were carried out in the retreat zone of Wyspianski icefall in the Low Head area (Antarctic Peninsula, South Shetland Islands archipelago, King George Island; Fig. 1), during the 29th Brazilian Antarctic Expedition.

About 500 grams of sediments were collected $30 \mathrm{~cm}$ depth, in the retreat zone of glacial plain. The sampling points were chosen based on distinct till deposits, as frontal moraines, lateral moraines, etc (Figure 2C). In the laboratory, samples were dried and sieved. For each sample, the sand and granule fragments were separated, attached with epoxy resin and prepared as thin sections for petrographic analyses, which were performed using transmitted light polarizer microscope. The fine silt and clay fractions were prepared for X-ray diffraction analysis, scanning electron microscopy and geochemical analysis of the major elements by X-ray fluorescence spectrometry.

The X-ray powder diffraction analyses were performed at the Laboratory of Photonic Nanometry, Federal University of Espírito Santo, Brazil, with RIGAKU conventional equipment, model Ultima IV, using $\mathrm{Cu} \mathrm{K}$ alpha radiation (average length $\langle\lambda\rangle=0.15419 \mathrm{~nm}$ ) using the Theta/2Theta Bragg-Bretano geometry. A 100-micrometer sieve was used to prepare the sediment powder samples for $\mathrm{X}$-ray diffraction measurements. NIST standard reference materials were used for calibration and setup (SRM 640d code- Silicon Powder (Si); SRM 660b code- Lanthanum Hexaboride $\left(\mathrm{LaB}_{6}\right)$ ) (Martinez et al., 2014).

To obtain the scanning electron microscope (SEM) images, the samples were coated with a fine gold film. The images of the mud fractions were obtained using a Shimadzu microscope, model SSX-550, at the Department of Physics, Federal University of Espírito Santo, Brazil.

To perform X-ray fluorescence spectrometry, 8 to 10 grams of each sample were mixed with 16 grams of organic binder material and pressed to make $35-\mathrm{mm}$ tablets. The analyses were performed at the Laboratory of Geochemistry, Department of Geology, Federal University of Espírito Santo, Brazil, with the S8 TIGER spectrometer with a lithium fluoride (LIF) 200 standard analyzer crystal. 

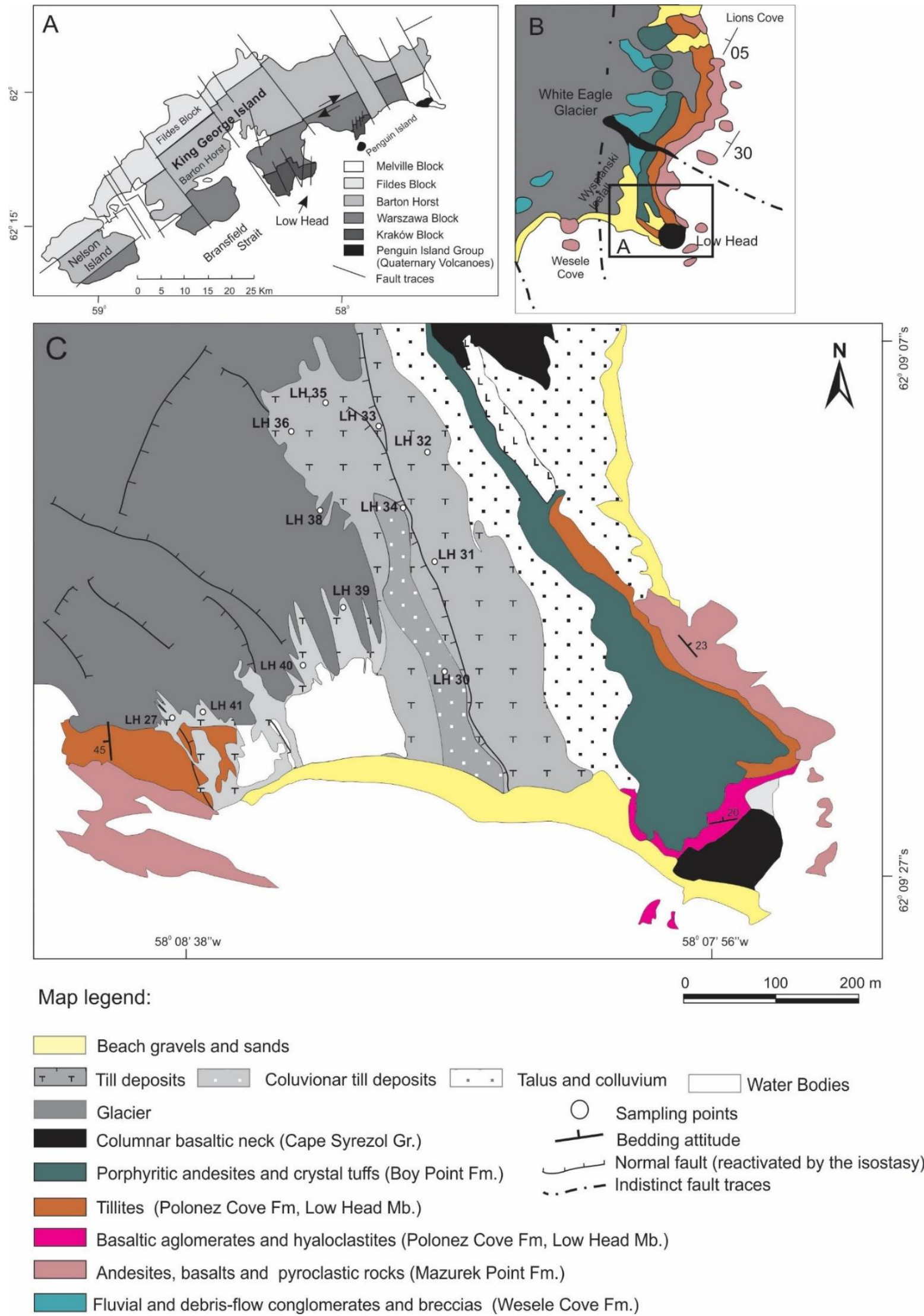

Fig. 2. A) tectonostratigraphic compartmentalization of King George Island. Modified from Birkenmajer (1983). (B) Geological sketch of Low Head, Wesele Cove and Lions Cove region, Krakow Block. Modified from Birkenmajer (2001). (C) Geological map in detail of Low Head. 
Major elements are expressed in weight percentage for oxides. Iron contents are expressed as the total iron $\left(\mathrm{Fe}_{2} \mathrm{O}_{3 \mathrm{t}}\right)$.

Glacial sediments were compared with parental rocks of South Shetland Islands utilizing data from Machado et al. (2005) (Livingstone, Greenwich, Robert and King George islands), Yeo et al. (2004) (Barton and Weaver peninsulas, King George Island) and Birkenmajer et al. (1991) (King George Island). The parental rocks dataset of Antarctic Peninsula is based on Saunders et al. (1980).

Simple correlation matrices were determined using the statistical mode of Libre Office, to test the degree of association among major elements in the sediments and rocks.

\section{Results}

\subsection{Petrography of the coarse fractions}

The sand and gravel size fractions in the till are composed mainly of rock fragments, including fragments of effusive, volcaniclastic and minor epiclastic rocks, as well as fragments of minerals, such as pyroxene, amphiboles and plagioclase (Table 1). Rock fragments are present mainly in the moraine deposits, whereas mineral fragments are common in the outwash deposits (Table 1; Figure 2C, sample LH 39).

Basalts and andesites are the main effusive rock fragments and generally make up more than $40 \%$ of the grains (Table 1). A range of textures, including porphyritic, trachytic, glomeroporphyritic and intersertal, were observed (Figs. 3A and 3B). In the outwash deposits, the percentage of effusive rock fragments decreases to about $25 \%$, whereas the proportion of mineral fragments increases (Table 1).

Pyroclastic rock fragments are represented by basaltic to andesitic tuffs and lapilli tuffs (Fig. 3C), which make up $25 \%$ to $41 \%$ of the grains (Table 1). Arkoses and lithic sandstones are the main constituents of the epiclastic rocks. Other clasts include quartz, microcline, carbonate and minor pyroxene and amphiboles (Fig. 5d), which make up between $1 \%$ and $10 \%$ of the grains (Table 1 ).

In the mineralogical grain assemblage of the sediments, plagioclase is the main constituent $(6 \%-28 \%)$, followed by pyroxene $(0 \%$ to $13.8 \%)$ and amphiboles $(0 \%$ to $3.7 \%)$ (Table 1). Trace minerals include quartz, carbonate, olivine, zircon and biotite.

\subsection{Chemical and mineralogical composition of the mud fractions}

The mud chemical composition shows that $\mathrm{SiO}_{2}$ ranges
RESEARCH PAPER

from $51.4 \%$ to $59.2 \%$, whereas $\mathrm{Fe}_{2} \mathrm{O}_{3 \mathrm{t}}$ (total iron oxides) varies from $7.9 \%$ to $12.8 \%$. The $\mathrm{Ca}_{2} \mathrm{O}$ varies from $6.6 \%$ to $9.1 \%$, and $\mathrm{MgO}$ ranges from $3.8 \%$ to $6.3 \%$ (Table 2).

Compared to the possible source areas, the chemical signature of till suggests more similarities with the South Shetland rocks than Antarctic Peninsula. In the chemical classification diagrams of magmatic series and rocks, used in this work to provenance purposes, the sedimentary till samples are clustered in the more concise field of South Shetland rocks, while the Antarctic Peninsula forms a more extended cluster (Fig. 4).

General chemical characteristics of parental rocks and derived sediments suggest basaltic and andesitic compositions in a calc-alkaline to tholeiitic series and metaluminous series (Fig. 4). On the other hand, the Antarctic Peninsula rocks has strictly calc-alkaline signature in a metaluminous to peraluminous series. The main geotectonic chemical signature indicates an orogenic background and a minor oceanic crust affinity (reflecting a spreading centre and oceanic ridge and floor) (Fig. 4).

The correlation matrices (Table $3 \mathrm{~A}$ and $3 \mathrm{~B}$ ) of chemical data from rocks from King George, Livingstone, Greenwich Islands and Antarctic Peninsula (Appendix 1), indicated correlations among $\mathrm{SiO}_{2}$ and $\mathrm{Al}_{2} \mathrm{O}_{3}, \mathrm{Fe}_{2} \mathrm{O}_{3}$ t, $\mathrm{CaO}$, $\mathrm{MgO}, \mathrm{TiO}_{2}, \mathrm{P}_{2} \mathrm{O}_{5}$ and $\mathrm{MnO}$. It could suggest fractionation of primary silicates, such as pyroxenes, amphiboles, Caplagioclases and olivine. The correlations of $\mathrm{Al}_{2} \mathrm{O}_{3}$ with respect to $\mathrm{Fe}_{2} \mathrm{O}_{3}$ t, $\mathrm{TiO}_{2}, \mathrm{P}_{2} \mathrm{O}_{5}$ and $\mathrm{MnO}$ could be associated with primary oxides, such as ilmenite, magnetite, hematite and phosphates such as apatite and minor monazite. The $\mathrm{Na}_{2} \mathrm{O}$ anomalies are probably due to the enrichment in $\mathrm{Na}$ plagioclase over $\mathrm{Ca}$-plagioclase. The relationship between $\mathrm{CaO}, \mathrm{Na}_{2} \mathrm{O}$ and $\mathrm{K}_{2} \mathrm{O}$ could be associated mainly with the occurrence of feldspars.

In the till, the correlation coefficients (Table 3C) show that $\mathrm{Fe}_{2} \mathrm{O}_{3}$ and $\mathrm{CaO}$ remain negatively correlated with $\mathrm{SiO}_{2}$, which likely reflects the main primary mineral phases, such as pyroxene, amphibole and plagioclase. The negative correlations with $\mathrm{TiO}_{2}$ are explained by the retention of detrital heavy minerals, such as ilmenite and (or) rutile, whereas the positive correlations with $\mathrm{Na}_{2} \mathrm{O}$ are related to its mobility in the surface environment.

The positive correlation between $\mathrm{Al}_{2} \mathrm{O}_{3}$ and $\mathrm{K}_{2} \mathrm{O}$ could be related to the presence of clay minerals, zeolites or $\mathrm{K}$ feldspars. The negative correlations of $\mathrm{CaO}$ with $\mathrm{Na}_{2} \mathrm{O}$ and $\mathrm{K}_{2} \mathrm{O}$ suggest its presence in plagioclase. Similar behavior of $\mathrm{Na}_{2} \mathrm{O}$ and $\mathrm{K}_{2} \mathrm{O}$ in the surface probably reflects the presence of clay or other secondary minerals in the sediments. All the correlations associated with $\mathrm{P}_{2} \mathrm{O}_{5}$ could be mainly related to apatite and minor relations with monazite clastic primary phases. 

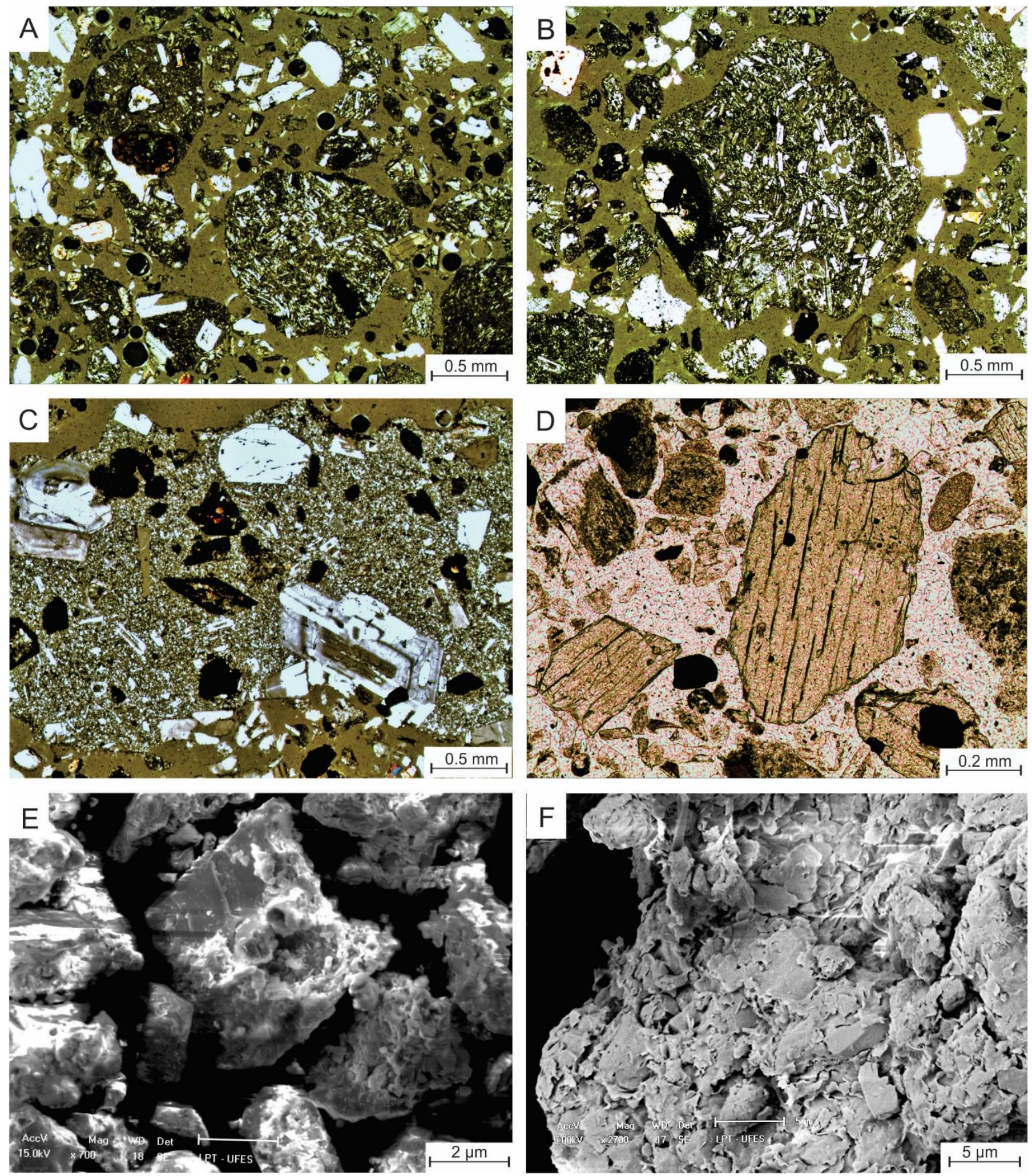

Fig. 3. A. Effusive basaltic and andesitic rock fragments exhibiting porphyritic and intersertal textures. Crossed polarizers. B. Detail of a basaltic grain with intersertal texture. Crossed polarizers. C. Pyroclastic rock fragments composed of crystalline lapilli in a microlitic and vitric ash matrix. Crossed polarizers. D. Detail of amphibole grains. Parallel polarizers. E. Image of an amphibole crystal under SEM in the mud size fractions. F. Image of detrital clay in SEM covering the surface of the grains. 
Tab. 1. Modal counting (\%) of the main sand and gravel size fraction constituents.

\begin{tabular}{|c|c|c|c|c|c|c|c|c|c|c|c|c|c|}
\hline Grain type & $\begin{array}{c}\text { LH } \\
30\end{array}$ & $\begin{array}{c}\text { LH } \\
31\end{array}$ & $\begin{array}{c}\text { LH } \\
38\end{array}$ & $\begin{array}{c}\text { LH } \\
27\end{array}$ & $\begin{array}{c}\text { LH } \\
32\end{array}$ & $\begin{array}{c}\text { LH } \\
33\end{array}$ & $\begin{array}{c}\text { LH } \\
34\end{array}$ & $\begin{array}{c}\text { LH } \\
41\end{array}$ & $\begin{array}{c}\text { LH } \\
35\end{array}$ & $\begin{array}{c}\text { LH } \\
36\end{array}$ & $\begin{array}{c}\text { LH } \\
40\end{array}$ & $\begin{array}{c}\text { LH } \\
39\end{array}$ & Average \\
\hline Effusive volcanic rock fragments & 45.9 & 40.7 & 35.6 & 44.7 & 45.3 & 45.4 & 53.6 & 39.14 & 34.2 & 47.7 & 50.2 & 25.1 & 42.3 \\
\hline Pyroclastic rock fragments & 28.1 & 38.0 & 26.7 & 23.2 & 30.2 & 30.6 & 25.4 & 39.75 & 41.6 & 25.4 & 27.7 & 27.3 & 30.3 \\
\hline $\begin{array}{l}\text { Sedimentary epiclastic rock } \\
\text { fragments }\end{array}$ & 2.4 & 2.8 & 2.5 & 1.2 & 5.4 & 9.9 & 3.5 & 8.40 & 7.1 & 5.4 & 10.1 & 1.3 & 5.0 \\
\hline Plagioclase & 12.2 & 12.2 & 16.0 & 14.2 & 12.2 & 9.2 & 16.5 & 6.91 & 14.6 & 15.7 & 11.9 & 28.6 & 14.2 \\
\hline Pyroxene & 0.0 & 6.0 & 13.8 & 13.0 & 5.5 & 0.7 & 0.7 & 5.43 & 2.5 & 5.8 & 0.0 & 9.0 & 5.2 \\
\hline Amphibole & 0.5 & 0.4 & 5.3 & 3.7 & 1.4 & 0.2 & 0.1 & 0.37 & 0.0 & 0.0 & 0.0 & 1.8 & 1.1 \\
\hline Others (carbonate. uartz, olivine, etc) & 10.8 & 0.0 & 0.0 & 0.0 & 0.0 & 4.0 & 0.1 & 0.0 & 0.0 & 0.0 & 0.0 & 6.9 & 1.8 \\
\hline
\end{tabular}

According to the X-ray diffractometric patterns (Fig. 5), the silt and clay fractions followed the indicated composition of the gravel and sand fractions. The primary mineralogical components include pyroxene, amphibole, plagioclase and quartz, which are typical of andesite and basalt compositions. Secondary products are indicated by brucite, saponite (a smectite-like clay) and laumontite, a common secondary hydrothermal zeolite in basaltic and andesitic rocks.

Well-defined crystals of amphibole and sheets of detrital clays that show broken edges and irregular distributions were detected using the SEM (Fig. 3E and 3F).

\section{Discussion}

The observed prevalence of feldspar and volcanic lithic fragments, rather than quartz and other stable grains, indicates a tectonically active source area. The provenance parameters of Dickinson et al. (1983) suggest that an undissected magmatic arc was the source area (Fig. 6A). This statement agrees with the compositional characteristics of an immature magmatic arc in the natural tectonic setting of the South Shetland Islands, instead of a more mature arc, related to the Antarctic Peninsula. This characteristic is supported by chemical data, which show that the inner arc of the Antarctic Peninsula has more extensive chemical characteristics, ranging from metaluminous to peraluminous, evidencing crustal recycling.

In volcanic rocks, glass and feldspar are very important in the weathering process, and they provide $\mathrm{Ca}, \mathrm{Na}$ and $\mathrm{K}$ to aqueous solutions. The $\mathrm{Al}_{2} \mathrm{O}_{3}$ is retained, and the feldspars change to clay minerals. In this sense, the chemical index of alteration (CIA) defined by Nesbitt and
Young (1982), indicates the parameters of some altered materials. CIA values ranging from 30 to 45 are associated with fresh basalts. On the other hand, CIA values between 45 and 55 are associated with fresh granites and granodiorites. Pleistocene till has CIA values of approximately 52, whereas these values in Pleistocene glacial clays range from 60 to 65 . The general CIA values for clays are 75-80 for illite, whereas kaolinite and chlorite have values closer to 100 (Nesbit and Young, 1982).

Both the volcanic rocks of King George, Livingstone, Greenwich islands, Antarctic Peninsula and the till of Low Head exhibit CIA values that range from 52 to 66 (Table 2 and 3). This range, which contains values that are higher than those of fresh basalts and acid rocks, demonstrates that these rocks suffered some degree of alteration, probably caused by hydrothermal alteration as described in previous works (Jeong et al., 2001, 2004; Simas et al., 2008; Monien et al., 2011). Canile (2010) identified an alteration process in some levels of the basalt sequence of the Mazurek Point Formation in Low Head, attributing to a chemical weathering process that acted during Eocene times. The similar values of CIA encountered in the sedimentary counterparts (till) of the regional rocks, could indicate the heritage of this alteration process.

The $\mathrm{SiO}_{2} / \mathrm{Al}_{2} \mathrm{O}_{3}$ ratio is a useful parameter in sediment maturity studies. It is sensitive to recycling and weathering processes. The average values of this parameter range from 3.0 in basic rocks to 5.0 in acidic rocks, whereas values from 5.0 to 6.0 or higher are typical of sediments, indicating progressive maturity (Dingle and Lavelle, 1998).

Clearly, ratios lower than the average values of rocks demonstrate $\mathrm{SiO}_{2}$ leaching and alteration, while greater values in sediments reflect increased compositional maturity due to the removal of aluminous mineral phases such as micas, plagioclase and clays. 


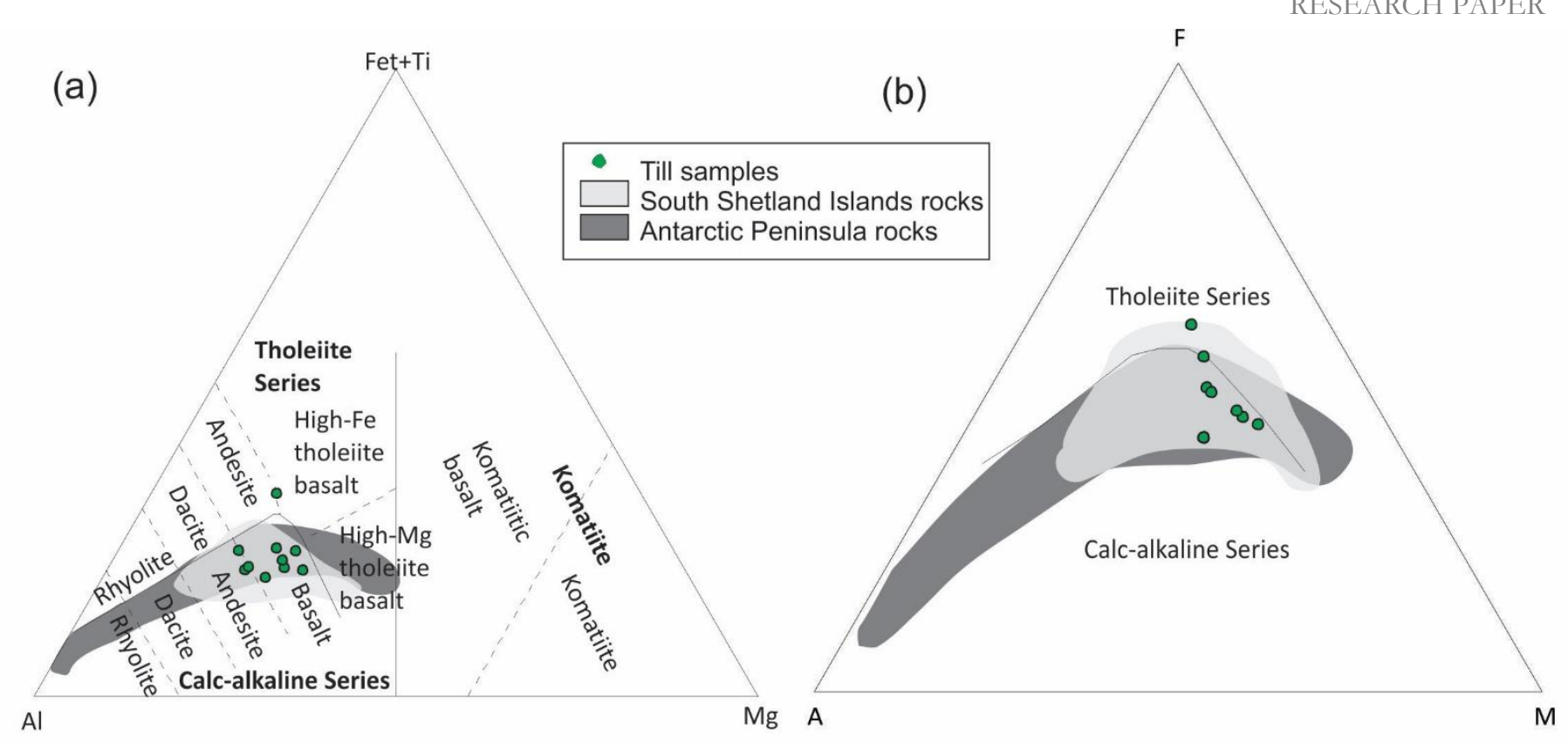

(c)

(d)
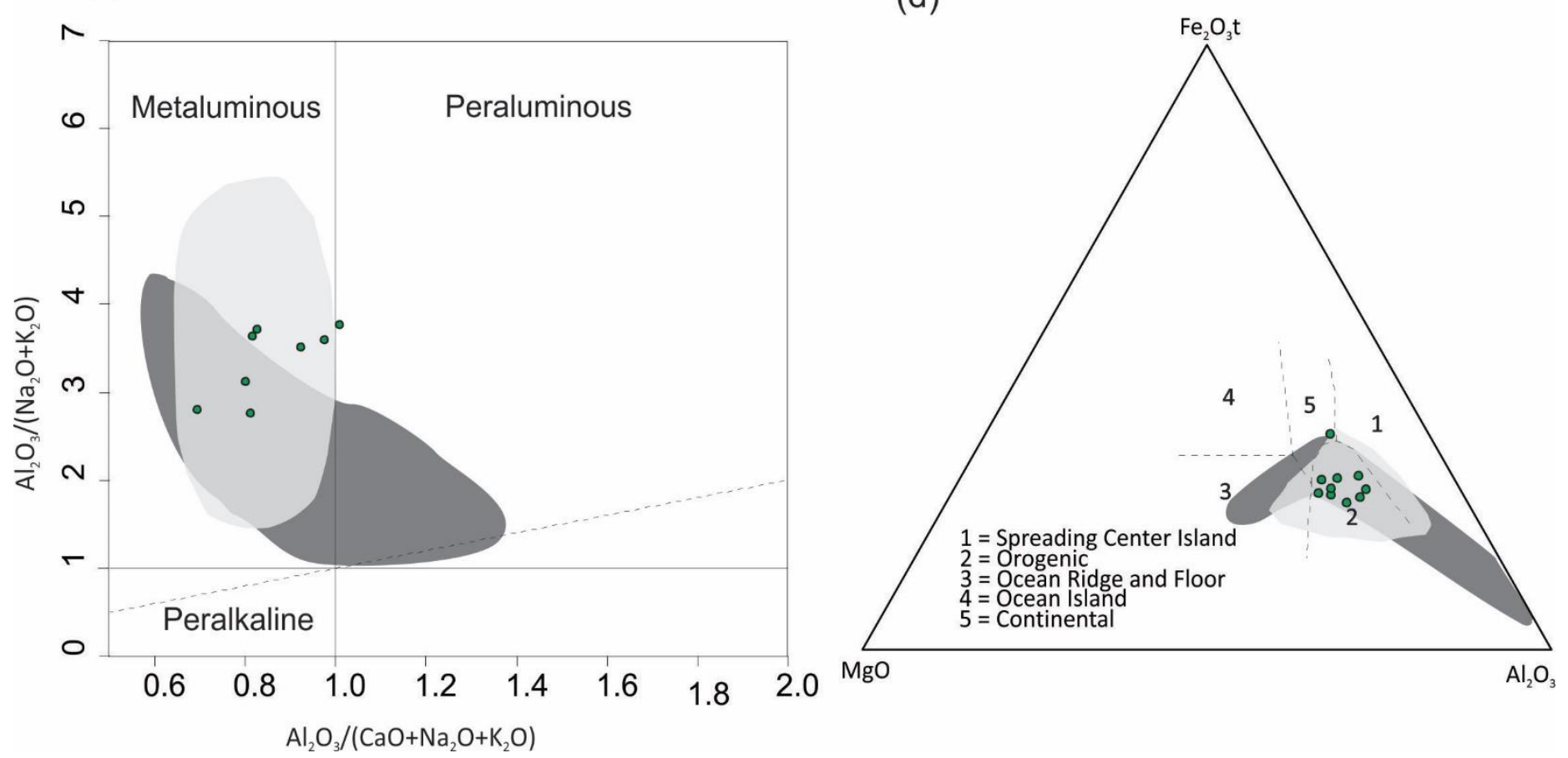

Fig. 4. Diagrams for comparison between parent rocks and glacial sediments: (a) Chemical classification of igneous rocks (Jensen, 1976) defining basaltic to andesitic parental rocks in the South Shetland Islands and basaltic to rhyolitic parental rocks in the Antarctic Peninsula. Fet is the total iron. (b) Diagram of magmatic series (Irvine and Baragar, 1971) defining a calc-alkaline to tholeiitic series for the rocks of the South Shetland Islands and Antarctic Peninsula. A: alkalis, F: Iron, M: Magnesium (c) Ratio diagram displaying aluminum against alkalis (Maniar and Piccoli, 1989) that defines a metaluminous series for the rocks of the South Shetland Islands and Metaluminous to peraluminous to the Antarctic Peninsula. (d) Tectonic discrimination diagram (Pearce et al., 1977) that defines manly an orogenic context for the South Shetland Islands and till sediments. $\mathrm{Fe}_{2} \mathrm{O}_{3} \mathrm{t}$ is the total iron. Observe that the general characteristics of the lithotypes in the South Shetland Islands are maintained in the till sediments, demonstrating the same regional provenance, while the rocks of Antarctic Peninsula exhibit more expanded characteristics. 


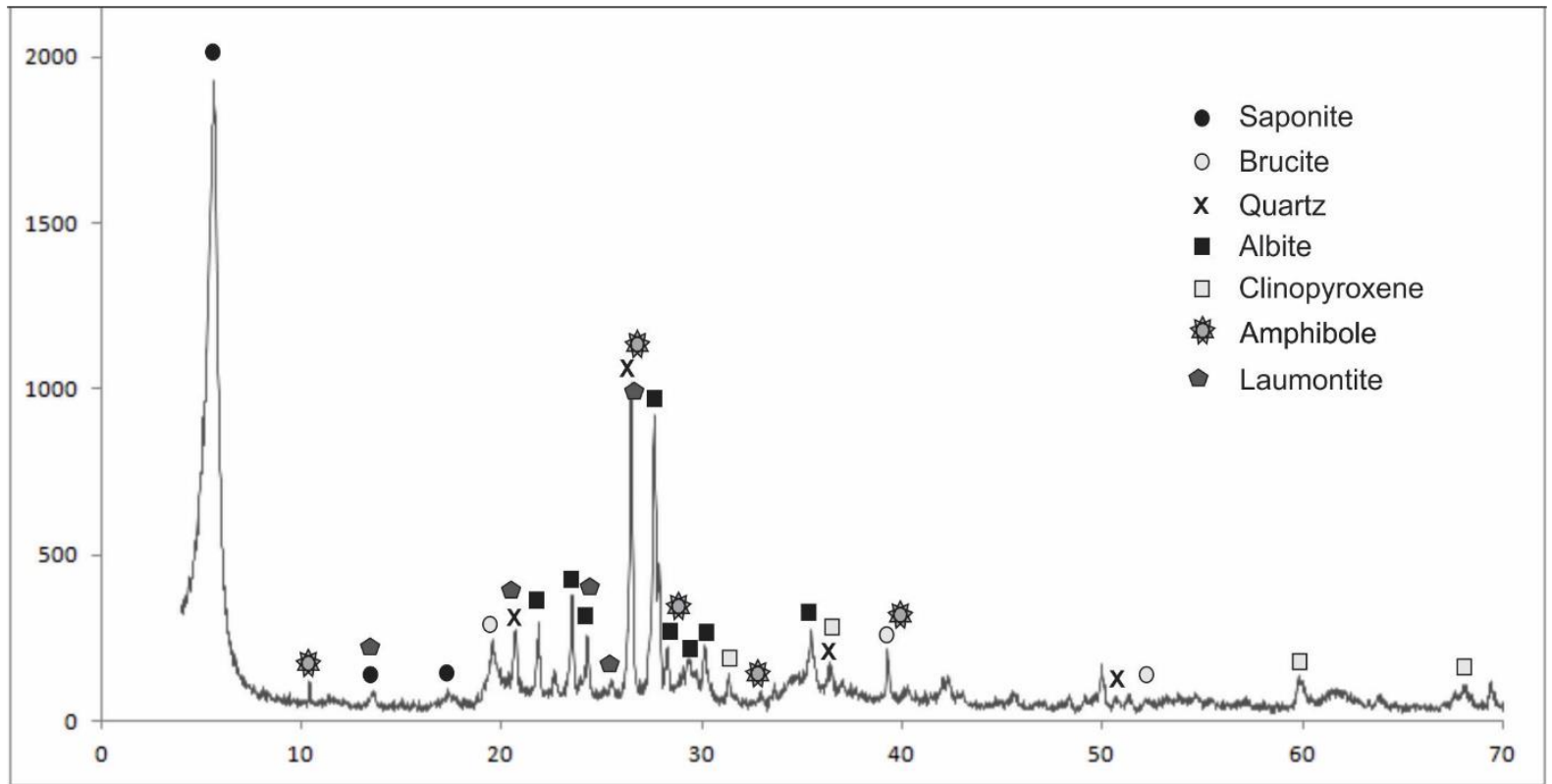

Fig. 5. Diffraction diagram $(\mathrm{CuK} \alpha,<\lambda>=0.15419 \mathrm{~nm})$ exhibiting the peaks corresponding to the main mineral phases present in mud fractions of the till deposits of Low Head, King George Island.

Tab. 2. Chemical analyses (\% Wt), chemical index of alteration (CIA) values and $\mathrm{SiO}_{2} / \mathrm{Al}_{2} \mathrm{O}_{3}$ ratios of till from Low Head, King George Island, Maritime Antarctic. $\mathrm{Fe}_{2} \mathrm{O}_{3 \mathrm{t}}$ represents total iron.

\begin{tabular}{ccccccccccccc}
\hline Sample & $\mathbf{S i O}_{2}$ & $\mathbf{A l}_{2} \mathbf{O}_{3}$ & $\mathbf{F e}_{2} \mathbf{O}_{3 \mathbf{t}}$ & $\mathbf{C a O}$ & $\mathbf{M g O}$ & $\mathbf{N a}_{2} \mathbf{O}$ & $\mathbf{K}_{2} \mathbf{O}$ & $\mathbf{T i O}_{2}$ & $\mathbf{P}_{2} \mathbf{O}_{5}$ & $\mathbf{M n O}$ & $\mathbf{C I A}$ & $\mathbf{S i O}_{2} / \mathbf{A l}_{2} \mathbf{O}_{3}$ \\
\hline $\mathbf{L H}$ - 30 & 58.07 & 16.42 & 8.98 & 8.25 & 3.89 & 2.12 & 0.81 & 0.93 & 0.21 & 0.16 & 59.49 & 3.54 \\
$\mathbf{L H}$ - 31 & 59.24 & 15.94 & 9.07 & 6.74 & 4.94 & 1.57 & 1.00 & 0.90 & 0.22 & 0.23 & 63.13 & 3.72 \\
$\mathbf{L H ~ - ~ 3 2 ~}$ & 57.18 & 16.36 & 8.82 & 6.64 & 6.34 & 2.02 & 1.13 & 0.86 & 0.25 & 0.21 & 62.56 & 3.50 \\
$\mathbf{L H ~ - ~ 3 3}$ & 58.69 & 17.26 & 8.34 & 6.91 & 4.19 & 1.88 & 1.31 & 0.86 & 0.20 & 0.17 & 63.08 & 3.40 \\
$\mathbf{L H ~ - ~ 3 5 ~}$ & 57.72 & 16.41 & 8.43 & 7.10 & 5.68 & 2.10 & 1.08 & 0.84 & 0.22 & 0.18 & 61.48 & 3.52 \\
$\mathbf{L H ~ - ~ 3 6}$ & 56.43 & 15.95 & 8.59 & 8.84 & 5.39 & 2.29 & 1.00 & 0.91 & 0.18 & 0.19 & 56.80 & 3.54 \\
$\mathbf{L H ~ - ~ 3 8}$ & 55.82 & 16.08 & 9.34 & 7.96 & 5.92 & 2.31 & 1.11 & 0.85 & 0.20 & 0.19 & 58.56 & 3.47 \\
$\mathbf{L H ~ - ~ 3 9}$ & 51.44 & 16.15 & 12.87 & 8.88 & 4.58 & 2.82 & 0.98 & 1.50 & 0.19 & 0.25 & 56.02 & 3.19 \\
$\mathbf{L H ~ - ~ 4 0}$ & 55.94 & 17.34 & 7.99 & 8.09 & 5.23 & 2.88 & 1.20 & 0.81 & 0.14 & 0.16 & 58.76 & 3.23 \\
$\mathbf{L H ~ - ~ 4 1}$ & 54.80 & 18.03 & 8.58 & 9.12 & 4.58 & 2.25 & 1.09 & 0.90 & 0.20 & 0.15 & 59.13 & 3.04 \\
\hline
\end{tabular}

The values of the $\mathrm{SiO}_{2} / \mathrm{Al}_{2} \mathrm{O}_{3}$ ratio, which fall between 1.8 and 3.8 in the set of rocks of South Shetland (Appendix 1), are lower or slightly higher than the basic rock pattern, demonstrating alteration of the fresh members. Regarding the sediments, the values of this ratio range from 3.0 to 3.7 (Table 2) demonstrating no substantial leaching of the material. Their chemical characteristics indicate mafic/intermediate parent rocks, as well as some level of $\mathrm{Al}_{2} \mathrm{O}_{3}$ removal, probably by the elimination of clay mineral phases. The Antarctic Peninsula rocks have $\mathrm{SiO}_{2} / \mathrm{Al}_{2} \mathrm{O}_{3}$ ratio values predominantly between 3.0 to 5.0 , higher than in sediments, indicating basic to acid fresh rocks, although some members have values higher than 5.0, which could indicate the presence of secondary mineral phases and $\mathrm{Al}_{2} \mathrm{O}_{3}$ removal.

The presence of secondary products such as saponite $\left((\mathrm{Mg}, \quad \mathrm{Fe})_{3}(\mathrm{Al}, \quad \mathrm{Si})_{4} \mathrm{O}_{10}(\mathrm{OH})_{2}(\mathrm{Ca}, \quad \mathrm{Na})_{0.3} * 4 \mathrm{H}_{2} \mathrm{O}\right)$ and laumontite $\left((\mathrm{Ca}, \mathrm{Na}, \mathrm{K}) \mathrm{Al}_{2} \mathrm{Si}_{4} \mathrm{O}_{12} * 4 \mathrm{H}_{2} \mathrm{O}\right)$ in the till might explain the behavior of $\mathrm{Na}_{2} \mathrm{O}, \mathrm{K}_{2} \mathrm{O}, \mathrm{CaO}$ and $\mathrm{Al}_{2} \mathrm{O}_{3}$ in the correlation matrix (Table 3), as well as in the CIA and $\mathrm{SiO}_{2} / \mathrm{Al}_{2} \mathrm{O}_{3}$ ratios.

The $\mathrm{SiO}_{2}$ and $\mathrm{Al}_{2} \mathrm{O}_{3}$ bivariate correlation diagrams, which compare the rocks (grey-shaded areas) and the till (Fig. 7), indicates overlapping for almost all elements, except to $\mathrm{Al}_{2} \mathrm{O}_{3}$ (that exhibit a distinct trend to the Antarctic Peninsula) and $\mathrm{Na}_{2} \mathrm{O}$. 
Tab. 3. Coefficients of correlation for major elements of magmatic volcanic and plutonic rocks from King George, Livingstone and Greenwich islands (a), Antarctic Peninsula (b) and till from Low Head, King George Island (c). Data from Machado et al., (2005), Yeo et al. (2004), Birkenmajer et al. (1991) and Saunders et al. (1980). Bold values in 6a are significant for $\alpha$ : 0.01 ( $n=106)$. Critical coefficients are $0.230(\alpha: 0.01)$ and $0.164(\alpha: 0.05)$. Bold values in $6 \mathrm{~b}$ are significant for $\alpha: 0.01(\mathrm{n}=21)$. Critical coefficients are $0.492(\alpha: 0.01)$ and $0.378(\alpha: 0.05)$. Bold values in 6c are significant for $\alpha: 0.05(\mathrm{n}=10)$. Critical coefficients are $0.715(\alpha: 0.01)$ and $0.549(\alpha: 0.05) . \mathrm{F}_{\mathrm{e}} 2 \mathrm{O}_{3 \mathrm{t}}$ represents total iron.

\begin{tabular}{|c|c|c|c|c|c|c|c|c|c|c|}
\hline A. & $\mathrm{SiO}_{2}$ & $\mathbf{A l}_{2} \mathbf{O}_{3}$ & $\mathrm{Fe}_{2} \mathrm{O}_{3 \mathrm{t}}$ & $\mathrm{CaO}$ & MgO & $\mathrm{Na}_{2} \mathrm{O}$ & $\mathbf{K}_{2} \mathbf{O}$ & $\mathrm{TiO}_{2}$ & $\mathbf{P}_{2} \mathbf{O}_{5}$ & $\mathrm{MnO}$ \\
\hline $\mathrm{SiO}_{2}$ & 1.000 & & & & & & & & & \\
\hline $\mathrm{Al}_{2} \mathbf{O}_{3}$ & -0.442 & 1.000 & & & & & & & & \\
\hline $\mathrm{Fe}_{2} \mathrm{O}_{3 \mathrm{t}}$ & -0.576 & -0.162 & 1.000 & & & & & & & \\
\hline $\mathrm{CaO}$ & -0.81 & 0.494 & 0.336 & 1.000 & & & & & & \\
\hline MgO & -0.613 & 0.013 & 0.279 & 0.564 & 1.000 & & & & & \\
\hline $\mathrm{Na}_{2} \mathrm{O}$ & 0.596 & -0.318 & -0.111 & -0.695 & -0.492 & 1.000 & & & & \\
\hline $\mathbf{K}_{2} \mathbf{O}$ & 0.439 & -0.259 & -0.205 & -0.608 & -0.37 & 0.123 & 1.000 & & & \\
\hline $\mathrm{TiO}_{2}$ & 0.058 & -0.483 & 0.615 & -0.254 & -0.086 & 0.373 & 0.162 & 1.000 & & \\
\hline $\mathbf{P}_{2} \mathbf{O}_{5}$ & 0.367 & -0.556 & 0.173 & -0.555 & -0.305 & 0.429 & 0.391 & 0.715 & 1.000 & \\
\hline $\mathrm{MnO}$ & -0.061 & -0.102 & 0.372 & -0.032 & 0.045 & 0.153 & -0.001 & 0.369 & 0.242 & 1.000 \\
\hline
\end{tabular}

\begin{tabular}{lcccccccccc}
\hline $\mathrm{B}$. & $\mathrm{SiO}_{2}$ & $\mathrm{Al}_{2} \mathrm{O}_{3}$ & $\mathrm{Fe}_{2} \mathrm{O}_{3 \mathrm{t}}$ & $\mathrm{CaO}$ & $\mathrm{MgO}$ & $\mathrm{Na}_{2} \mathrm{O}$ & $\mathrm{K}_{2} \mathrm{O}$ & $\mathrm{TiO}_{2}$ & $\mathrm{P}_{2} \mathrm{O}_{5}$ & $\mathrm{MnO}$ \\
\hline $\mathrm{SiO}_{2}$ & 1.000 & & & & & & & & & \\
$\mathrm{Al}_{2} \mathrm{O}_{3}$ & -0.73 & 1.000 & & & & & & & & \\
$\mathrm{Fe}_{2} \mathrm{O}_{3 \mathrm{t}}$ & -0.98 & 0.719 & 1.000 & & & & & & & \\
$\mathrm{CaO}$ & -0.95 & 0.648 & 0.931 & 1.000 & & & & & & \\
$\mathrm{MgO}$ & -0.92 & 0.474 & 0.86 & 0.89 & 1.000 & & & & & \\
$\mathrm{Na}_{2} \mathrm{O}$ & $\mathbf{0 . 2 9 9}$ & -0.14 & -0.282 & -0.309 & -0.46 & 1.000 & & & & \\
$\mathrm{~K}_{2} \mathrm{O}$ & $\mathbf{0 . 8 7 4}$ & -0.757 & -0.849 & -0.908 & -0.735 & 0.046 & 1.000 & & & \\
$\mathrm{TiO}_{2}$ & -0.86 & 0.707 & 0.89 & 0.756 & 0.693 & 0.018 & -0.753 & 1.000 & & \\
$\mathrm{P}_{2} \mathrm{O}_{5}$ & -0.69 & 0.622 & 0.679 & 0.571 & 0.55 & 0.238 & -0.656 & 0.894 & 1.000 & \\
$\mathrm{MnO}_{n} \mathrm{-0.85}$ & $\mathbf{0 . 6 6 9}$ & $\mathbf{0 . 8 8 9}$ & $\mathbf{0 . 8 2}$ & $\mathbf{0 . 6 9 1}$ & $\mathbf{0 . 0 2 7}$ & -0.823 & 0.893 & 0.811 & 1.000 \\
\hline
\end{tabular}

\begin{tabular}{|c|c|c|c|c|c|c|c|c|c|c|}
\hline C. & $\mathrm{SiO}_{2}$ & $\mathrm{Al}_{2} \mathrm{O}_{3}$ & $\mathrm{Fe}_{2} \mathrm{O}_{3 \mathrm{t}}$ & $\mathrm{CaO}$ & $\mathrm{MgO}$ & $\mathrm{Na}_{2} \mathrm{O}$ & $\mathbf{K}_{2} \mathbf{O}$ & $\mathrm{TiO}_{2}$ & $\mathbf{P}_{2} \mathbf{O}_{5}$ & $\mathrm{MnO}$ \\
\hline $\mathrm{SiO}_{2}$ & 1.000 & & & & & & & & & \\
\hline $\mathrm{Al}_{2} \mathrm{O}_{3}$ & -0.084 & 1.000 & & & & & & & & \\
\hline $\mathrm{Fe}_{2} \mathrm{O}_{3 \mathrm{t}}$ & -0.735 & -0.379 & 1.000 & & & & & & & \\
\hline $\mathrm{CaO}$ & -0.721 & 0.217 & 0.343 & 1.000 & & & & & & \\
\hline MgO & 0.006 & -0.345 & -0.173 & -0.327 & 1.000 & & & & & \\
\hline $\mathrm{Na}_{2} \mathrm{O}$ & -0.805 & 0.184 & 0.391 & 0.661 & 0.025 & 1.000 & & & & \\
\hline $\mathbf{K}_{2} \mathbf{O}$ & 0.110 & 0.493 & -0.369 & -0.376 & 0.266 & 0.016 & 1.000 & & & \\
\hline $\mathrm{TiO}_{2}$ & -0.757 & -0.254 & 0.968 & 0.434 & -0.308 & 0.447 & -0.362 & 1.000 & & \\
\hline $\mathbf{P}_{2} \mathbf{O}_{5}$ & 0.365 & -0.314 & 0.028 & -0.564 & 0.247 & -0.714 & -0.179 & -0.078 & 1.000 & \\
\hline $\mathrm{MnO}$ & -0.300 & -0.696 & 0.741 & -0.183 & 0.230 & -0.034 & -0.222 & 0.658 & 0.298 & 1.000 \\
\hline
\end{tabular}




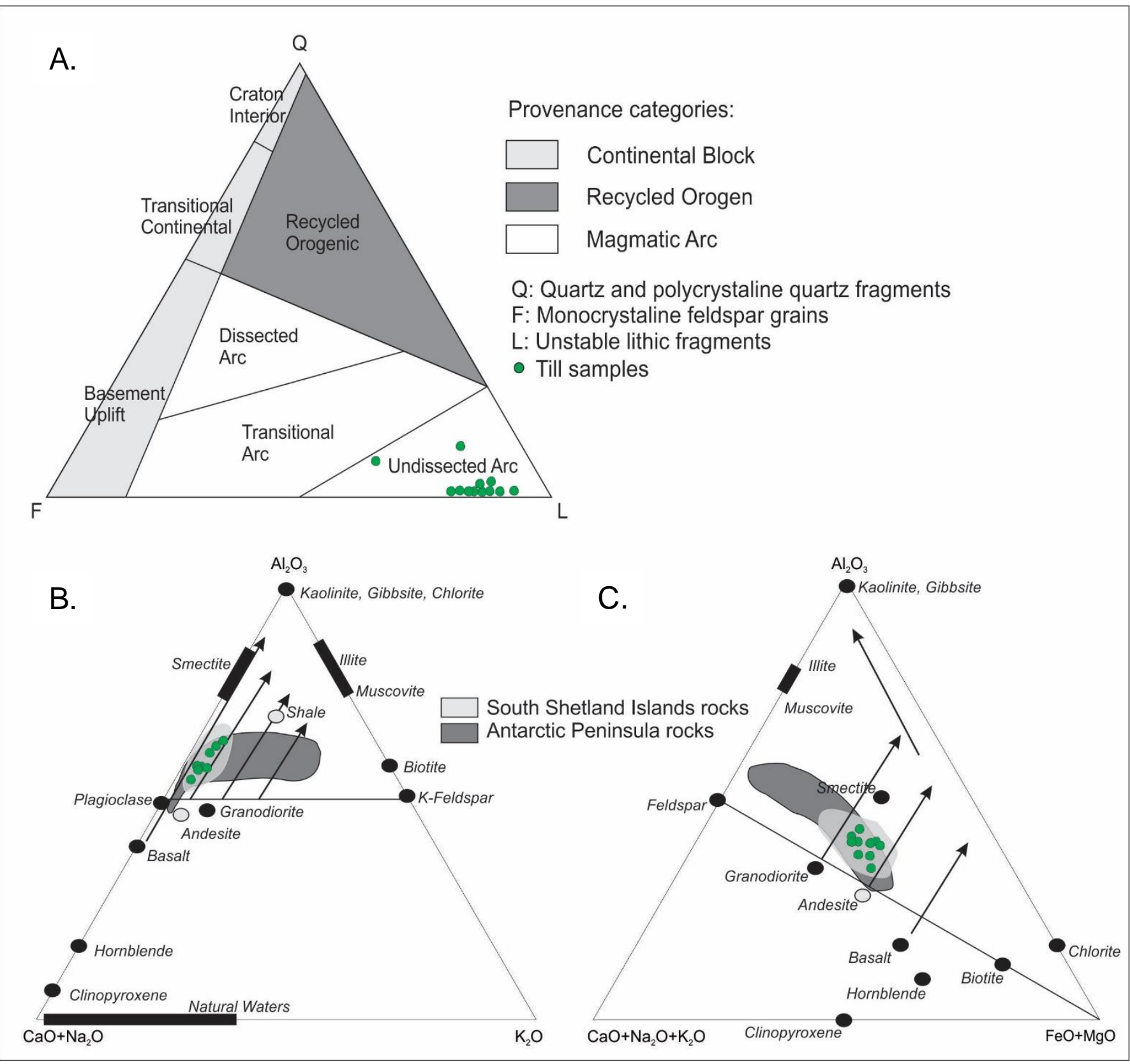

Fig. 6. A. Ternary plots of provenance from Dickinson et al. (1983). B. and C.: plots of weathering of McLennan et al. (1993), showing trends of the till sediments from Low Head. Observe in B. a trend above the andesite and plagioclase fields, toward the smectite field and clays vertex. In C., the samples exhibit a cluster between andesite and granodiorite, toward the smectite.

The behavior of $\mathrm{Al}_{2} \mathrm{O}_{3}$ corroborates the discrimination diagrams of series of Maniar and Piccoli (1989) (Fig. 4) and with the $\mathrm{SiO}_{2} / \mathrm{Al}_{2} \mathrm{O}_{3}$ ratio (Appendix 1), suggesting that the parental rocks of King George Island could be associated strictly to the South Shetland, with none or few contributions of the Antarctic Peninsula.

Considering the possible parental rocks from South Shetland, the behavior of $\mathrm{MgO}, \mathrm{Na}_{2} \mathrm{O}$ and $\mathrm{Fe}_{2} \mathrm{O}_{3 \mathrm{t}}$ in the till, outside the corresponding domain, suggest some mobility, which could be associated with the presence of the secondary mineral phases (Fig. 7). This result indicates that, although regional rocks demonstrate some degree of hydrothermal alteration, including the formation of laumontite, the till sediments may have suffered some small degree of weathering, leading to the formation of clay and hydroxide minerals. 

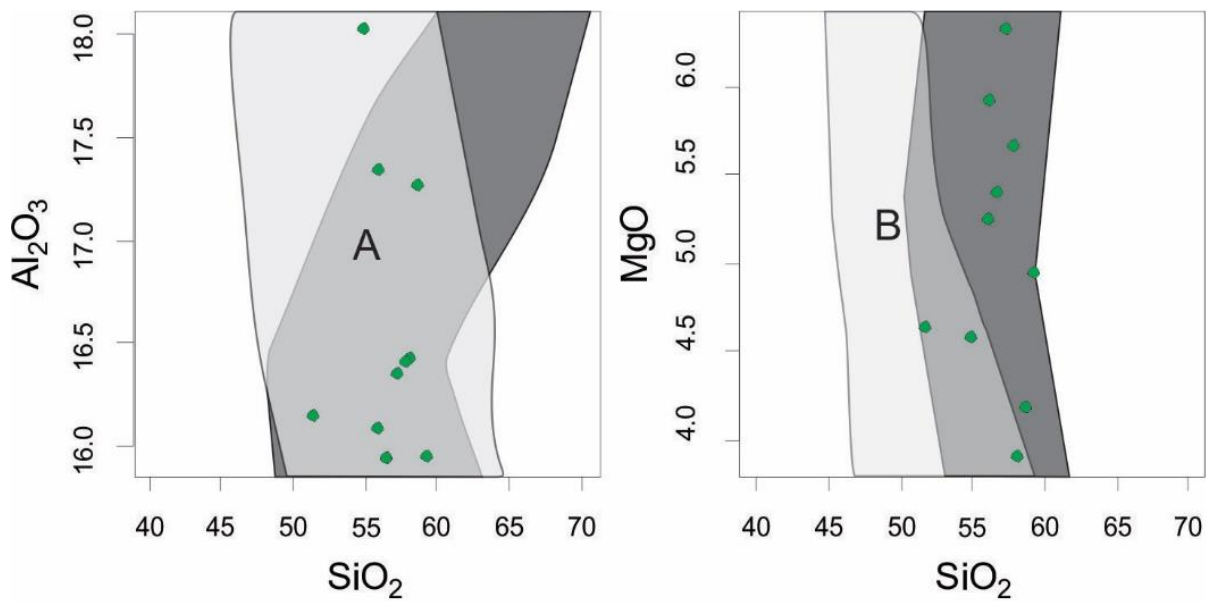

RESEARCH PAPER
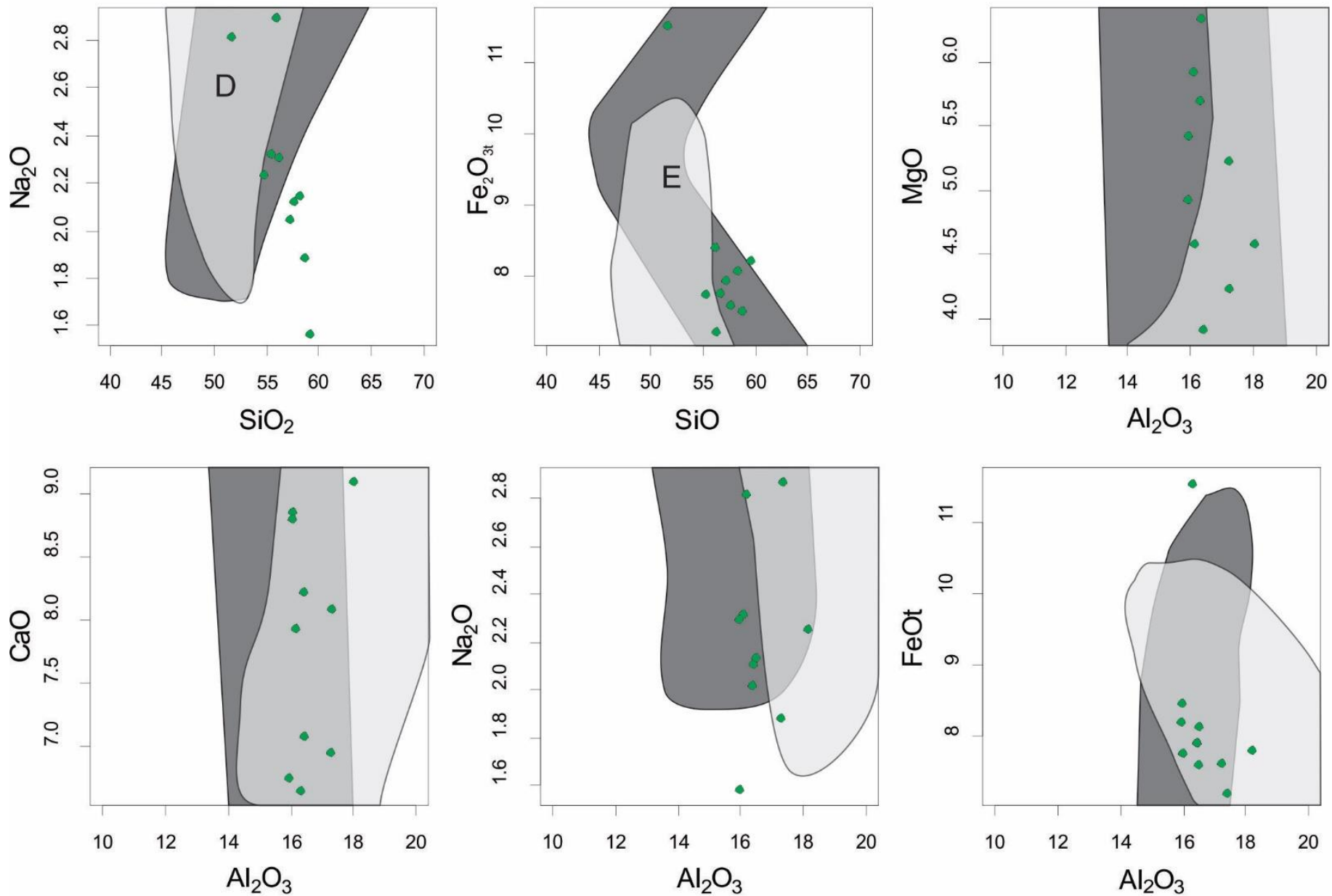

Legend:
A: Clinopyroxene + Plagioclase
B: Clinopyroxene + Clinoamphibole \pm Olivine
C: Plagioclase+Clinopyroxene+ Amphibole
D: Clinopyroxene+Plagioclase
E: Clinopyroxene+Olivine+Amphibole

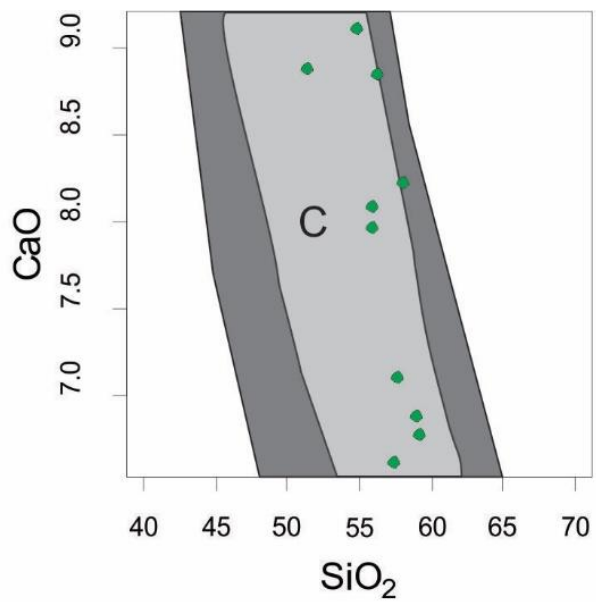

Fig. 7. Bivariate correlation diagrams comparing the rocks (grey-shaded areas) and till sediments from Low Head, King George Island. Observe the behavior of $\mathrm{Al}_{2} \mathrm{O}_{3}, \mathrm{CaO}, \mathrm{MgO}, \mathrm{Na}_{2} \mathrm{O}$ and $\mathrm{Fe}_{2} \mathrm{O}_{3} \mathrm{t}$ (total iron oxides), which fall outside of the domain of the South Shetland Island rocks. 
Ternary plots of weathering (McLennan et al., 1993) also confirm that the till and South Shetland rocks suffered some level of alteration. In the alkalis and aluminum plot, the samples tend to plot above the andesite and plagioclase fields, towards the smectite field and the clays vertex. In the alkalis and $\mathrm{Fe}_{2} \mathrm{O}_{3 \mathrm{t}}$ plus $\mathrm{MgO}$ diagram, the samples tend to plot between the andesite and granodiorite, towards the smectite area (Fig. 6B and 6C). The trends of Antarctic Peninsula rocks indicate a series of fresh rocks, from more basic to acid alkaline members (Fig. 6B and 6C).

\section{Conclusion}

The predominance of effusive and pyroclastic rock fragments over epiclastic and grains of minerals, such as plagioclase and clinopyroxene, indicate that these sediments are derived from the immature magmatic arc rocks. The geochemical characteristics of the possible provenance areas suggest that the till sediments of Low Head have more similarities with the South Shetland Island than the Antarctic Peninsula. Although Birkenmajer (1980) had described an influence of parental rocks from the Antarctic Peninsula in the Krakowiak Glacier Member, Polonez Cove Formation. Additionally, the calc-alkaline and metaluminous chemical signatures of these rocks, which were produced in an orogenic context, were maintained in the sediments.

The main chemical differences between the parental rocks and sediments were detected in the correlation matrices among $\mathrm{SiO}_{2}$ and $\mathrm{Al}_{2} \mathrm{O}_{3}$ with $\mathrm{Na}_{2} \mathrm{O}, \mathrm{K}_{2} \mathrm{O}, \mathrm{MnO}$, and $\mathrm{Fe}_{2} \mathrm{O}_{3}$ t, suggesting the presence of secondary mineral phases. On the bivariate plots, these differences are clearly demonstrated by the fields where the samples were plotted $\left(\mathrm{MgO}, \mathrm{Na}_{2} \mathrm{O}\right.$ and $\left.\mathrm{Fe}_{2} \mathrm{O}_{3 t}\right)$, which lie slightly outside the areas defined by the South Shetland rocks. The CIA index of Nesbit and Young (1982) and the $\mathrm{SiO}_{2} / \mathrm{Al}_{2} \mathrm{O}_{3}$ ratios indicate the effects of some alteration or weathering in the rocks of the source area and their sedimentary counterparts. The ternary plots of weathering also suggest trends of clay development towards smectite. The presence of secondary mineral phases, such as laumontite, saponite and brucite, was confirmed by X-ray diffractometry. SEM images demonstrated that the clays in the till suffered some level of transportation.

The results indicate that probably the saponite and brucite may have developed in some instance of the sedimentary cycle with further transportation of the material or were derived from Eocene weathered basalts, while the laumontite likely formed due to hydrothermal alteration of parental rocks.

Although sediments in this study represent a specific locality in King George Island, they have an important significance to understand the regional development of retreat zones and the provenance of the till, showing
RESEARCH PAPER

general similarities and congruencies with regional rocks of South Shetland Islands and the alteration processes suffered by them.

\begin{abstract}
Acknowledgment
This paper is dedicated to the memory to all who have lost their lives in the Comandante Ferraz Station, in the 2012 fire. The field data presented here are the legacy of two campaigns carried out in 2011 and 2012. Owing to the fire and complete destruction of the Comandante Ferraz Antactic station, all the work and samples of 2012, regarding the Ecology and Baranowski glaciers were lost. The authors also would like to thank the Brazilian Antarctic Program/ CNPq (PROANTAR), the Brazilian Navy and the Brazilian Air Force for providing material resources and logistical support during the field work and research.
\end{abstract}

\section{References}

Barton, C.M., 1965. The geology of the South Shetland Islands: III. The stratigraphy of King George Island. Birmingham, British Antarctic Survey 33p.

Birkenmajer, K., 2001. Mesozoic and Cenozoic stratigraphic units in parts of the South Shetland and Northern Antartic Peninsula. Studia Geologica Polonica 118, 5-188.

Birkenmajer, K., 1994. Evolution of the Pacific margin of the northern Antarctic Peninsula: an overview. Geologische Rundschau 83, 309-321. https://doi.org/10.1007/BF00210547

Birkenmajer, K., 1992a. Evolution of the Bransfield basin and rift, West Antarctica. Recent Progress in Antarctic Earth Science 405-410.

Birkenmajer, K., 1992b. Cenozoic glacial history of the South Shetland Islands and Northern Antarctic Peninsula. In: III Congresso geológico España y VIII Congresso Latinoamericano de Geologia. Universidad de Salamanca, pp. 251-260.

Birkenmajer K., Francalancp L., Peccerill, A., 1991. Petrological and geochemical constraints on the genesis of MesozoicCenozoic magmatism of King George Island, South Shetland Islands, Antarctic. Antarctic Science 3(3), 293-308.

Birkenmajer, K., 1989. King George Island. In: Dalziel I.W.D., Birkenmajer K., Mpodoziz C., Ramos V.A., Thomson M.R.A. (eds.), International Geological Congress Field Trip Guidebook, pp. 114-121.

Birkenmajer, K., 1983. Late Cenozoic phases of block-faulting on King George: a revised lithostratigraphic standard for the Tertiary of King George Island (South Shetlands Islands, West Antarctic). Bulletin de l'Académie polonaise des sciences, Série des sciences de la Terre 30, 21-32.

Birkenmajer, K., 1980. A revised lithostratigraphic standard for the Tertiary of King George Island (South Shetlands Islands, Antartica). Bulletin de l'Academie Polonaise des Sciences 27, 49-57.

Canile, F.M., 2010. Evidências geológicas de mudanças climáticas (greenhouse-icehouse) na Antártica Ocidental durante a passagem Eoceno-Oligoceno. MSc Dissertation, Universidade de São Paulo, São Paulo, Brazil, 97p. HTTPS:/ / doi.org/10.11606/D.44.2010.tde-08012011-203025 
Cook, J.A., Fox, A.J., Vaughan, D.G., Ferrigno, J.G., 2005. Retreating glacier fronts on the Antarctic Peninsula over the past half century. Science 308, 541-544. https://doi.org/10.1126/science. 1104235

Dalziel, IW.D., 1984. Tectonic evolution of a forearc terrane, southern Scotia Ridge, Antarctic. Geological Society of America 200. https://doi.org/10.1130/SPE200-p1

Dickinson, W.R., Beard, L.S., Brakenridge, G.R., Erjavec, J.L., Ferguson, R.C., Inman, K.F., Knepp, R.A., Lindberg F.A., Ryberg, P.T., 1983. Provenance of North American Phanerozoic sandstones in relation to tectonic setting. Geological Society of America Bulletin 94(2), 222-235. https://doi.org/10.1130/0016-606(1983)94

Dingle R.V., Lavelle M. 1998. Late Cretaceous-Cenozoic climatic variations of the northern Antarctic Peninsula: new geochemical evidence and review. Palaeogeography, Palaeoclimatology, Palaeoecology 141(3), 215-232. https://doi.org/10.1016/S0031-0182(98)00056-X

Gledhill, A., Rex, D.C., Tanner, P.W.G., 1982. Rb-Sr and K-Ar geochronology of rocks from the Antarctic Peninsula between Anvers Island and Marguerite Bay. Antarctic Geoscience 315, 323.

Hawkes, D.D., 1961. The Geology of the South Shetland Islands. Birmingham, Falkland Islands Dependencies Survey, 43p.

Hervé, F., Miller, H., Pimpirev, C., 2006. Patagonia-Antarctic connections before Gondwana break-up. In: Augustin, L., Barbante, C., Barnes, P.R.F., et al. (eds.). Antarctic. Berlin, Springer, pp. 217-227. https://doi.org/10.1007/3-54032934-X_26

Hyden, G., Tanner, P.W.G., 1981. Late Palaeozoic-early Mesozoic fore-arc basin sedimentary rocks at the Pacific margin in western Antarctic. Geologische Rundschau 70, 529-541. https://doi.org/10.1007/BF01822133

Irvine, T.N., Baragar, W.R.A., 1971. A guide to the chemical classification of the common volcanic rocks. Canadian Journal of Earth Sciences 8(5), 523-548. https://doi.org/10.1139/e71-055

Jensen, L.S., 1976. A new cation plot for classifying subalkaline volcanic rocks. Ontario, Ministry of Natural Resources Miscellaneous Papers, 66, 22 p.

Jeong, G.Y., Yoon, H.I., 2001. The origin of clay minerals in soils of King George Island, South Shetland Islands, west Antarctic, and its implications for the clay-mineral composition of marine sediments. Journal of Sedimentary Research 71(5), 833-842. https://doi.org/10.1306/2DC4096C-0E47-11D78643000102C1865D

Jeong, G.Y., Yoon, H.I., Lee, S.Y., 2004. Chemistry and microstructures of clay particles in smectite-rich shelf sediments, South Shetland Islands, Antarctic. Marine Geology 209, 19-30. https://doi.org/10.1016/j.margeo.20xt04.05.027

Machado, A., Lima, E.F., Chemale, F., Moratab, D., Oteizab, O., Almeida, D.P.M., Figueiredo, A.M.G., Alexandre, F.M., Urrutia, J.L., 2005. Geochemistry constraints of MesozoicCenozoic calc-alkaline magmatism in the South Shetland arc, Antarctic. Journal of South American Earth Sciences 18, 407425. https://doi.org/10.1016/j.jsames.2004.11.011

Maniar, P.D., Piccoli, P.M., 1989. Tectonic discrimination of granitoids. Bulletin of geological Society of America 101, 635643. https://doi.org/0.1130/0016-7606(1989)101
RESEARCH PAPER

Martinez, L.G., Ichikawa, R.U., Imakuma, K., Orlando, M.T.D., Turrillas, X., 2014. Synchrotron diffraction characterization of alternative powder diffraction standards. São Paulo, Edgard Blücher, pp. 115-117.

McLennan, S.M., Hemming, S., McDaniel, D.K., Hanson, G.N., 1993. Geochemical approaches to sedimentation, provenance, and tectonics. Geological Society of America Special Papers 284, 21-40. https://doi.org/10.1130/SPE284p. 21

Michel, R.F.M., Schaefer, C.E.G.R., Dias, L., Simas, F.N.B., Benites, V., Mendonça, E.S., 2006. Ornithogenic gelisols (cryosols) from Maritime Antarctic- pedogenesis, vegetation and carbon studies. Soil Science Society of America Journal 70, 1370-1376. doi:10.2136/sssaj2005.0178

Monien, P., Schnetger, B., Brumsack, H., Hass, H.C., Kuhn, G., 2011. A geochemical record of late Holocene paleoenvironmental changes at King George Island (maritime Antarctic). Antarctic Science 23, 255-267. doi:10.1017/S095410201100006X

Nesbitt, H.W., Young, G.M., 1982. Early Proterozoic climates and plate motions inferred from major element chemistry of lutites. Nature 299, 715-7 17.

Pearce T.H., Gorman, B.E., Birkett, T.C., 1977. The relationship between major element chemistry and tectonic environment of basic and intermediate volcanic rocks. Earth and Planetary Science Letters 36, 121-132. https://doi.org/10.1016/0012821X(77)90193-5

Robert C., Kennett, J.P., 1997. Antarctic continental weathering changes during Eocene-Oligocene cryosphere expansion: Clay mineral and oxygen isotope evidence. Geology 25(7), 587-590. https://doi.org/https://doi.org/10.1130/00917613(1997)025<0587:ACWCDE > 2.3.CO;2

Rückamp, M., Braun, M., Suckro, S., Blindow, N., 2011. Observed glacial changes on the King George Island ice cap, Antarctic, in the last decade. Global and Planetary Changes 79, 99-109. https://doi.org/10.1016/j.gloplacha.2011.06.009

Santos, I.R., Fávero, D.I.T., Schaefer, C.E.G.R., Silva-Filho, E.V., 2007. Sediment geochemistry in coastal maritime Antarctic (Admiralty Bay, King George, Island): Evidence from rare earths and other elements. Marine Chemistry 107, 464-474. https://doi.org/10.1016/j.marchem.2007.09.006

Saunders, A.D., Tarney, J.W., Weaver, S.D., 1980. Transverse geochemical variations across the Antarctic Peninsula: implications for the genesis of calc-alkaline magmas. Earth and Planetary Science Letters 46(3), 344-360. https://doi.org/10.1016/0012-21X(80)90050-3

Schaefer, C.E.G.R, Simas, F.N.B., Gilkes, R.J., Mathison, C., Costa, L.M., 2008. Micromorphology and microchemistry of Cryosols from Maritime Antarctic. Geoderma 144, 104-115. https://doi.org/10.1016/j.geoderma.2007.10.018

Simas, F.N.B., Schaefer, C.E.G.R., Albuquerque Filho, M.R., Francelino, M.R., Fernandes Filho, E.I., Costa, L.M., 2008. Genesis, properties and classification of Cryosols from Admiralty Bay, Maritime Antarctic. Geoderma 144, 116-122. https://doi.org/10.1016/j.geoderma.2007.10.019

Trouw, R.A.J., Pankhurst, R.J., Ribeiro, A., 1997. On the relation between the Scotia metamorphic complex and the Trinity Peninsula Group, Antarctic Peninsula. In: Ricci, C.A., (ed.), The Antarctic regions: geological evolution and processes. Siena, Terra Antartica Publication, 385-389. 
Vaughan, A.P.M., Storey, B.C., 2000. The eastern Palmer Land shear zone: a new terrane accretion model for the Mesozoic development of the Antarctic Peninsula. Journal of the Geological Society 157(6), 1243-1256. https://doi.org/10.1144/jgs.157.6.1243
RESEARCH PAPER

Yeo, J.P., Lee, J.I., Do Hur, S., Choi, B.G., 2004. Geochemistry of volcanic rocks in Barton and Weaver peninsulas, King George Island, Antarctic: implications for arc maturity and correlation with fossilized volcanic centres. Geosciences Journal 8(1), 11-25. https://doi.org/10.1007/BF02910275 


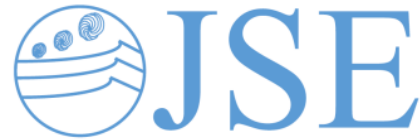

RESEARCH PAPER

Appendix 1. Major element chemical analyses (\% Wt), chemical index of alteration (CIA) values and $\mathrm{SiO}_{2} / \mathrm{Al}_{2} \mathrm{O}_{3}$ ratios of magmatic volcanic and plutonic rocks from King George, Livingstone and Greenwich Islands and Antarctic Peninsula. Data from Machado et al. (2005), Yeo et al. (2004), Birkenmajer et al. (1991) and Saunders et al. (1980). $\mathrm{Fe}_{2} \mathrm{O}_{3 \mathrm{t}}$ represents total iron.

\begin{tabular}{|c|c|c|c|c|c|c|c|c|c|c|c|c|c|}
\hline & Sample & $\mathrm{SiO}_{2}$ & $\mathrm{Al}_{2} \mathrm{O}_{3}$ & $\mathrm{Fe}_{2} \mathrm{O}_{3 \mathrm{t}}$ & $\mathrm{CaO}$ & MgO & $\mathrm{Na}_{2} \mathrm{O}$ & $\mathbf{K}_{2} \mathbf{O}$ & $\mathrm{TiO}_{2}$ & $\mathbf{P}_{2} \mathbf{O}_{5}$ & $\mathrm{MnO}$ & CIA & $\mathrm{SiO}_{2} / \mathrm{Al}_{2} \mathrm{O}_{3}$ \\
\hline \multirow{40}{*}{ 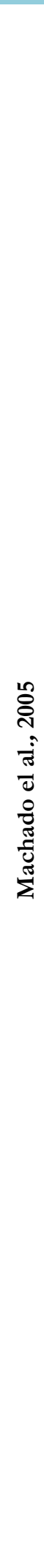 } & 101 & 46.91 & 23.15 & 7.83 & 11.00 & 4.61 & 2.66 & 0.51 & 0.62 & 0.09 & 0.16 & 62.03 & 2.03 \\
\hline & 102 & 49.80 & 18.68 & 9.04 & 11.70 & 5.85 & 2.46 & 0.58 & 0.75 & 0.22 & 0.17 & 55.89 & 2.67 \\
\hline & 103 & 50.19 & 19.89 & 9.64 & 9.97 & 4.31 & 3.31 & 0.57 & 0.84 & 0.13 & 0.18 & 58.95 & 2.52 \\
\hline & 104 & 50.34 & 20.56 & 7.59 & 10.90 & 6.15 & 2.16 & 0.79 & 0.45 & 0.09 & 0.12 & 59.75 & 2.45 \\
\hline & 105 & 50.50 & 19.70 & 10.28 & 9.78 & 4.33 & 3.14 & 0.48 & 0.84 & 0.13 & 0.17 & 59.52 & 2.56 \\
\hline & 106 & 50.98 & 19.05 & 9.06 & 10.73 & 5.08 & 2.90 & 0.30 & 0.78 & 0.16 & 0.15 & 57.76 & 2.68 \\
\hline & 107 & 52.03 & 18.73 & 9.20 & 8.10 & 3.91 & 3.58 & 1.34 & 1.06 & 0.26 & 0.20 & 58.99 & 2.78 \\
\hline & 108 & 52.14 & 17.96 & 10.05 & 7.79 & 3.73 & 3.58 & 0.67 & 0.85 & 0.15 & 0.18 & 59.87 & 2.90 \\
\hline & 109 & 52.30 & 18.85 & 9.03 & 7.76 & 4.75 & 3.89 & 0.92 & 0.84 & 0.19 & 0.11 & 59.99 & 2.77 \\
\hline & 110 & 52.64 & 20.64 & 7.96 & 10.39 & 4.25 & 1.84 & 0.40 & 0.71 & 0.12 & 0.14 & 62.04 & 2.55 \\
\hline & 111 & 53.22 & 17.18 & 8.22 & 8.35 & 4.68 & 3.18 & 1.03 & 0.88 & 0.14 & 0.14 & 57.77 & 3.10 \\
\hline & 112 & 54.16 & 19.08 & 8.03 & 8.48 & 3.70 & 3.14 & 0.91 & 0.78 & 0.21 & 0.20 & 60.36 & 2.84 \\
\hline & 113 & 54.89 & 18.57 & 7.99 & 8.49 & 3.72 & 3.51 & 0.80 & 0.78 & 0.20 & 0.15 & 59.20 & 2.96 \\
\hline & 114 & 55.39 & 19.19 & 8.81 & 7.34 & 2.90 & 4.06 & 0.92 & 0.70 & 0.22 & 0.16 & 60.90 & 2.89 \\
\hline & 115 & 57.16 & 17.34 & 8.03 & 7.15 & 3.13 & 4.30 & 0.81 & 0.96 & 0.27 & 0.29 & 58.58 & 3.30 \\
\hline & 116 & 60.92 & 16.81 & 6.58 & 5.25 & 2.85 & 3.46 & 1.02 & 0.97 & 0.31 & 0.16 & 63.34 & 3.62 \\
\hline & 117 & 51.73 & 18.15 & 9.06 & 9.92 & 5.35 & 2.91 & 0.52 & 0.80 & 0.16 & 0.16 & 57.62 & 2.85 \\
\hline & 118 & 53.78 & 17.14 & 9.78 & 7.53 & 4.89 & 3.03 & 0.77 & 0.98 & 0.22 & 0.15 & 60.20 & 3.14 \\
\hline & 119 & 55.72 & 17.05 & 8.34 & 7.55 & 4.14 & 3.13 & 0.92 & 0.91 & 0.21 & 0.14 & 59.51 & 3.27 \\
\hline & 120 & 47.47 & 25.74 & 8.67 & 9.33 & 3.06 & 3.23 & 0.45 & 0.83 & 0.04 & 0.12 & 66.43 & 1.84 \\
\hline & 121 & 53.95 & 18.87 & 8.49 & 9.20 & 4.57 & 2.95 & 0.20 & 0.78 & 0.11 & 0.16 & 60.44 & 2.86 \\
\hline & 122 & 55.99 & 17.40 & 7.46 & 7.26 & 3.89 & 3.67 & 1.05 & 0.61 & 0.13 & 0.14 & 59.22 & 3.22 \\
\hline & 123 & 48.09 & 16.93 & 9.50 & 10.03 & 8.86 & 2.66 & 0.58 & 0.97 & 0.35 & 0.14 & 56.06 & 2.84 \\
\hline & 124 & 49.13 & 17.64 & 9.38 & 9.65 & 7.76 & 3.17 & 0.68 & 0.95 & 0.26 & 0.16 & 56.65 & 2.79 \\
\hline & 125 & 49.21 & 18.20 & 9.56 & 10.31 & 7.47 & 2.58 & 0.28 & 0.91 & 0.14 & 0.16 & 58.02 & 2.70 \\
\hline & 126 & 49.31 & 17.50 & 9.60 & 10.82 & 8.00 & 2.51 & 0.21 & 0.89 & 0.15 & 0.17 & 56.38 & 2.82 \\
\hline & 127 & 49.40 & 18.30 & 8.90 & 10.54 & 7.33 & 2.64 & 0.30 & 0.79 & 0.13 & 0.14 & 57.58 & 2.70 \\
\hline & 128 & 48.41 & 20.51 & 9.55 & 12.29 & 4.73 & 2.47 & 0.28 & 1.11 & 0.17 & 0.14 & 57.69 & 2.36 \\
\hline & 129 & 48.40 & 18.29 & 9.24 & 11.51 & 7.59 & 2.37 & 0.42 & 0.91 & 0.18 & 0.16 & 56.12 & 2.65 \\
\hline & 130 & 49.50 & 15.90 & 12.80 & 9.30 & 4.20 & 3.60 & 0.62 & 1.42 & 0.21 & 0.18 & 54.04 & 3.11 \\
\hline & 131 & 49.60 & 17.30 & 11.60 & 9.30 & 4.10 & 3.90 & 0.33 & 1.31 & 0.28 & 0.18 & 56.11 & 2.87 \\
\hline & 132 & 50.40 & 16.00 & 10.30 & 11.20 & 6.20 & 3.10 & 0.26 & 0.97 & 0.16 & 0.14 & 52.36 & 3.15 \\
\hline & 133 & 50.54 & 17.03 & 9.57 & 9.65 & 8.01 & 2.88 & 0.19 & 1.10 & 0.23 & 0.18 & 57.24 & 2.97 \\
\hline & 134 & 50.70 & 15.90 & 11.40 & 9.40 & 5.20 & 3.70 & 0.81 & 1.18 & 0.19 & 0.16 & 53.34 & 3.19 \\
\hline & 135 & 53.07 & 16.93 & 9.23 & 10.30 & 6.45 & 2.66 & 0.50 & 0.70 & 0.08 & 0.17 & 55.71 & 3.13 \\
\hline & 136 & 53.60 & 15.90 & 11.30 & 7.50 & 3.09 & 4.10 & 1.35 & 1.63 & 0.44 & 0.17 & 55.11 & 3.37 \\
\hline & 137 & 53.88 & 19.63 & 8.34 & 8.80 & 2.79 & 3.97 & 0.96 & 1.02 & 0.13 & 0.13 & 58.84 & 2.74 \\
\hline & 138 & 54.00 & 16.00 & 10.10 & 7.00 & 2.60 & 4.40 & 0.68 & 1.57 & 0.60 & 0.21 & 56.98 & 3.38 \\
\hline & 139 & 55.46 & 15.27 & 11.02 & 7.24 & 3.59 & 3.99 & 1.05 & 1.35 & 0.27 & 0.19 & 55.43 & 3.63 \\
\hline & 140 & 56.73 & 17.42 & 7.55 & 6.27 & 3.08 & 4.15 & 1.03 & 0.74 & 0.24 & 0.20 & 60.34 & 3.26 \\
\hline
\end{tabular}




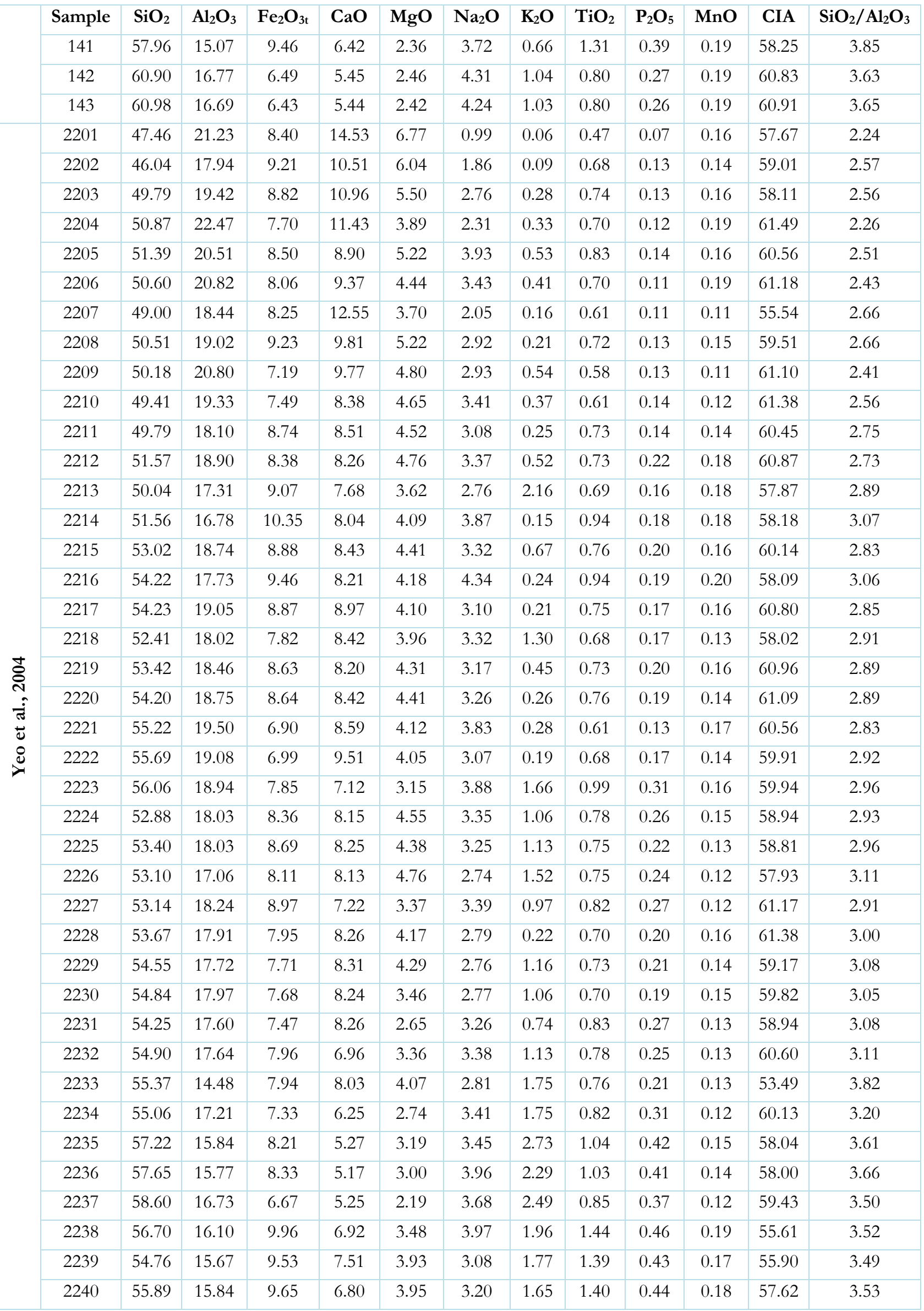




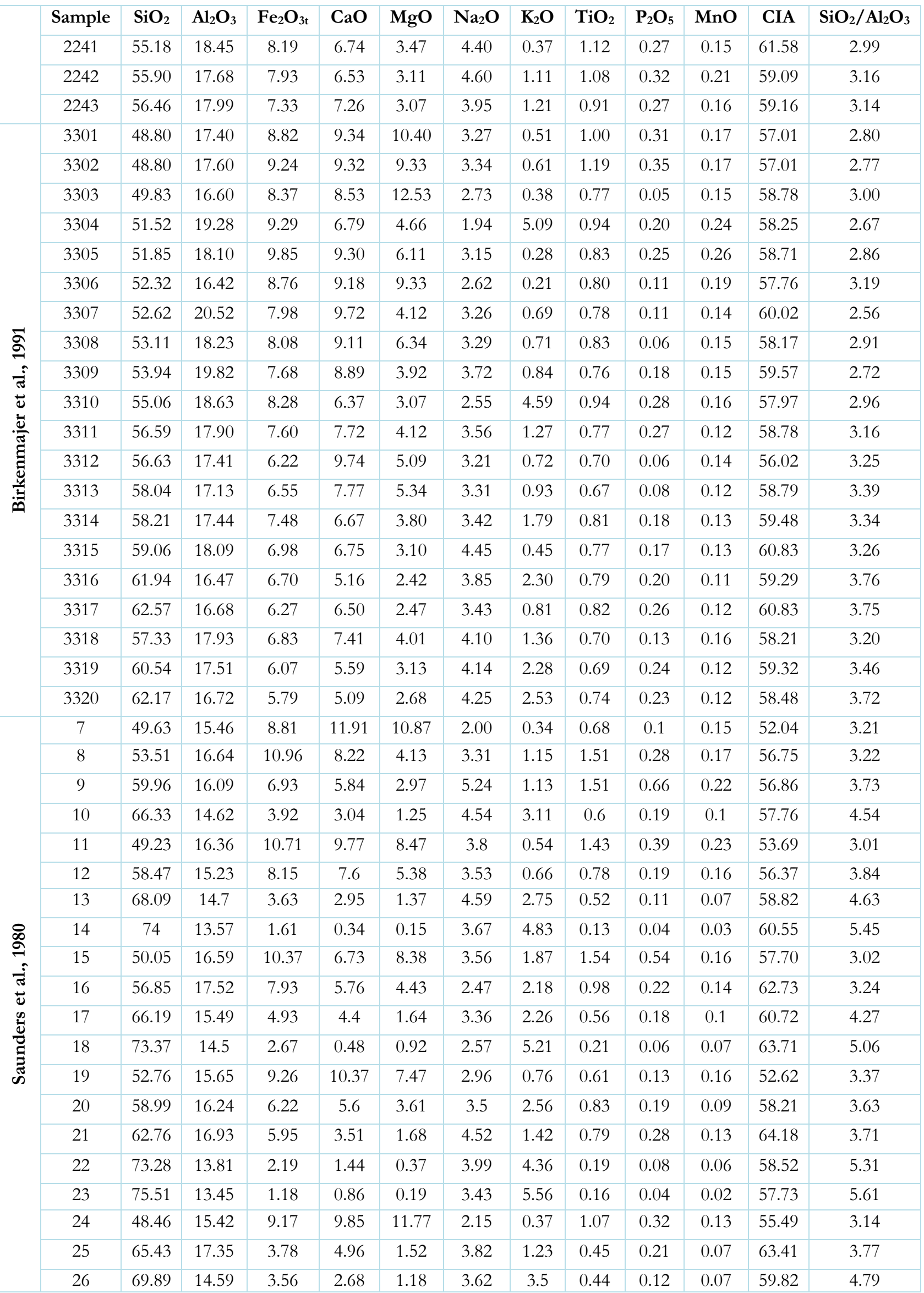


RESEARCH PAPER

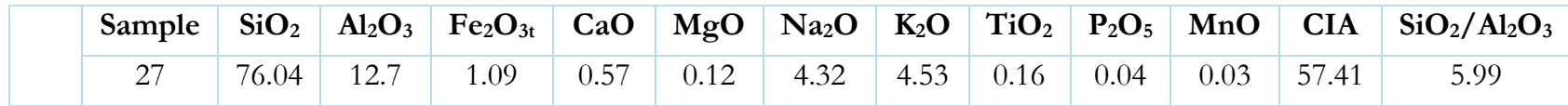

